\title{
Antiviral and immunomodulatory effects of
} polyphenols on macrophages infected with dengue virus serotypes 2 and 3 enhanced or not with antibodies

This article was published in the following Dove Press journal:

Infection and Drug Resistance

\author{
Carolina Jasso-Miranda ${ }^{1,2}$ \\ Irma Herrera-Camacho ${ }^{2}$ \\ Lilian Karem Flores- \\ Mendoza ${ }^{3}$ \\ Fabiola Dominguez' \\ Veronica Vallejo-Ruiz' \\ Gilma Guadalupe Sanchez- \\ Burgos ${ }^{4}$ \\ Victoria Pando-Robles ${ }^{5}$ \\ Gerardo Santos-Lopez' \\ Julio Reyes-Leyva'
}

\begin{abstract}
'Laboratory of Immunology and Virology, East Biomedical Research Center, Mexican Institute of Social Security (IMSS), CP 74360 Metepec, Puebla, México; ${ }^{2}$ Laboratory of Biochemistry and Molecular Biology, Center of Chemistry, Institute of Sciences, Meritorious Autonomous University of Puebla, CP 72570 San Manuel, Puebla, Mexico;

${ }^{3}$ Department of Chemical, Biologic and Agricultural Sciences, Science and Enginery Division, University of Sonora, CP 85880 Navojoa, Sonora, Mexico;

${ }^{4}$ Yucatan's Medical Research Unit, Mexican Institute of Social Security (IMSS), CP 97I50 Merida, Yucatan, Mexico; ${ }^{5}$ Infectious Disease Research Center, National Institute of Public Health, CP 62100 Cuernavaca, Morelos, Mexico
\end{abstract}

Correspondence: Julio Reyes-Leyva Centro de Investigación Biomédica de Oriente (CIBIOR), Instituto Mexicano del Seguro Social (IMSS), Km 4.5 carretera Atlixco-Metepec, CP 74360, Metepec, Puebla, México

Tel +52 2223089820

Email julio.reyes@imss.gob.mx
Background: There is a lack of specific antiviral therapy against dengue virus (DENV) in current use. Therefore, a great proportion of dengue cases progress to severe clinical forms due to a complex interplay between virus and host immune response. It has been hypothesized that heterotypic non-neutralizing antibodies enhance DENV infection in phagocytic cells, and this induces an inflammatory response that is involved in the pathogenesis of severe dengue.

Purpose: To identify the antiviral and immunomodulatory effects of polyphenols on dengue virus infection.

Methods: Human U937-DC-SIGN macrophages were infected with DENV serotypes 2 or 3 in the presence or not of enhancing antibody 4G2. Viral titers and the secretion of tumor necrosis factor-alpha, IL-6, IL-10 and interferon-alpha were analyzed timely.

Results: DENV infection alone induced high production of IL- 6 and TNF- $\alpha$, but in the presence of 4G2 antibody, viral titers and TNF- $\alpha$ secretion were potentiated. Based on antiinflammatory antecedents, the polyphenols curcumin, fisetin, resveratrol, apigenin, quercetin and rutin were tested for antiviral and immunomodulatory properties. Only quercetin and fisetin inhibited DENV-2 and DENV-3 infection in the absence or presence of enhancing antibody ( $>90 \%, p<0.001)$; they also inhibited TNF- $\alpha$ and IL-6 secretion $(p<0.001)$.

Conclusion: Quercetin and fisetin down-regulate the production of proinflammatory cytokines induced by DENV infection enhanced by antibodies a mechanism involved in severe dengue.

Keywords: dengue, proinflammatory cytokines, TNF- $\alpha$, enhancing antibody, immunopathogenesis

\section{Introduction}

Dengue is one of the most important human viral diseases worldwide. It is estimated that 390 million dengue infections occur annually of which 96 million are symptomatic and 20,000 are fatal. ${ }^{1}$ In addition to the public health concern, there is a major economic and social impact in countries where large dengue epidemics occur, often disrupting primary care services due to the number of patients requiring medical attention and hospitalization. ${ }^{2-4}$

Dengue virus (DENV) belongs to the genus Flavivirus, family Flaviviridae, its genome is a positive sense RNA that codes for three structural $(\mathrm{C}, \mathrm{prM}$ and $\mathrm{E})$ and 
seven nonstructural proteins (NS1, NS2A, NS2B, NS3, NS4A, NS4B and NS5). Four DENV serotypes (DENV-1 to 4) have been identified, and all are associated with the disease.

Dengue is an acute febrile disease with arthralgia, rash, hemorrhagic symptoms and thrombocytopenia. Patients may deteriorate to severe dengue characterized by intense hemorrhage, plasma leakage and in some cases shock, organ impairment and death. ${ }^{5,6}$ In the last decades, an increase in the proportion of severe dengue cases has been observed. Severe dengue is the result of a complex interplay between virus and host immune factors, including increased infection of immune cells due to the presence of nonneutralizing antibodies, activation of cross-reactive autoantibodies and $\mathrm{T}$ cells, as well as deregulation of cytokine, complement and coagulation cascades. ${ }^{7,8}$

It has been hypothesized that antibody-dependent enhancement (ADE) of infection occurs during secondary or tertiary infections when non-neutralizing antibodies against heterologous DENV serotypes interact with Fc receptors increasing the infection of monocytes and macrophages. ${ }^{9-11}$ In consequence, ADE potentiates secretion of cytokines that play a critical role in the pathogenesis of severe dengue. ${ }^{12,13}$ Many studies found that high levels of interferon-alpha (IFN- $\alpha$ ), IL-8, IL-6, tumor necrosis factor-alpha (TNF- $\alpha$ ) IL-10 and IFN- $\gamma$ are correlated with severe dengue at different stages of the disease. ${ }^{14-17}$ In addition, overexpression of the suppressors of cytokine signaling is found in patients with dengue. ${ }^{17,18}$ Therefore, modulation of cytokine secretion could be a primary target of the research on antiviral drugs against dengue.

There is no antiviral treatment or effective vaccines to control DENV infection in current use. Dengue therapy is limited to fluid recovery and supportive care in patients with hypovolemic shock; thus, good management of fluids and continuous monitoring is the key to succeed and avoid fatal complications. ${ }^{19}$

Effective anti-dengue drugs is yet an unmet need although intensive research. ${ }^{20}$ Some clinical trials have tested repurposed drugs such as chloroquine, prednisolone, balapiravir, celgosivir and lovastatin; however, they have not been successful at decreasing viral load and antigenemia or inducing a beneficial effect to dengue patients. ${ }^{20,21}$

Ethnopharmacology has contributed significantly to the discovery of new drugs. ${ }^{22}$ Some studies have found several polyphenols with anti-dengue potential activities such as 7-0-methyl-glabranine, ${ }^{23}$ catanospermine, ${ }^{24}$ quercetin and fisetin. ${ }^{25,26}$
Here, we expanded the study of polyphenols to identify their immunomodulatory effects on ADE of DENV infection in macrophages.

\section{Materials and methods \\ Cells}

C6/36 cells (ATCC ${ }^{\circledR}$ CRL-1660 ${ }^{\mathrm{TM}}$ ) were cultured in Eagle's minimal essential medium (MEM, Caisson) supplemented with $10 \%$ fetal bovine serum (FBS, Biowest) at $27^{\circ} \mathrm{C}$. C6/36 cells were used for DENV replication and production of virus stocks.

BHK-21 cells $\left(\right.$ ATCC $^{\circledR}$ CCL-10 ${ }^{\mathrm{TM}}$ ) were cultured in MEM supplemented with 5\% FBS, $27 \mathrm{mM}$ 4-(2-hydroxyethyl)-1-piperazineethanesulfonic acid (HEPES) and $42 \mathrm{mM}$ sodium bicarbonate at $37^{\circ} \mathrm{C}$ in $95 \%$ air, $5 \% \mathrm{CO}_{2}$ and humid atmosphere. BHK-21 cells were used to determine viral titers.

U937 cells (ATCC ${ }^{\circledR}$ CRL-1593.2) and U937-DC-SIGN cells (ATCC ${ }^{\circledR}$ CRL-3252) were kindly provided by Dr. Rosa Maria del Angel from CINVESTAV, Mexico. Cells were maintained in RPMI-1640 culture medium supplemented with 5\% FBS, $27 \mathrm{mM}$ HEPES and $42 \mathrm{mM}$ sodium bicarbonate at $37^{\circ} \mathrm{C}$ in $95 \%$ air, $5 \% \mathrm{CO}_{2}$ and humid atmosphere. These cells have the morphology and phenotype of monocytes, and they were differentiated into macrophages by treatment with $10 \mathrm{ng} / \mathrm{mL}$ phorbol 12-myristate 13-acetate (PMA) for 24 hrs. After that, cells were washed, fresh medium was added, and cells rested $24 \mathrm{hrs}$ before any other treatment or infection was done. Most of the assays described later were performed in U937-DC-SIGN cells either undifferentiated (monocytes) or PMA-differentiated (macrophages). From here and forward, we will refer to them just as monocytes or macrophages.

\section{Virus}

Reference DENV serotype 2 (New Guinea strain, 16,681) was donated by Dr. Aguilar Setién from the Laboratory of Virology, Medical Research Unit on Immunology, IMSS. DENV serotype 3 (DENV-3) was isolated from clinical samples during the dengue outbreak occurred at Yucatan State in 2011 and was identified as DENV by reverse transcription-polymerase chain reaction (RT-PCR) using reported primers ${ }^{27}$ at CISEI, National Institute of Public Health, Morelos Mexico. Viral serotype was confirmed by real-time RT-PCR procedures performed at Central Laboratory of Epidemiological Surveillance, Mexican Institute of Social Security, Mexico City. 


\section{DENV replication in U937-DC-SIGN cells}

Monocytes and macrophages seeded in 6-well plates $\left(2 \times 10^{6}\right.$ cells/well $)$ were either not infected or infected with DENV at a multiplicity of infection (MOI) of 1 plaque-forming unit (PFU) per cell. Viral inoculum was removed after $1 \mathrm{hr}$ of incubation and $2 \mathrm{~mL}$ of fresh RPMI supplemented with 5\% FBS was added. Samples of cell supernatants were obtained at 6, 12, 24, 48, 72 and $96 \mathrm{hrs}$ postinfection (hpi). Collected supernatants were centrifuged at $3,500 \mathrm{rpm}$ and aliquoted at $-80^{\circ} \mathrm{C}$ for the subsequent determination of cytokines and virus titers.

\section{Antibody-dependent enhancement of infection}

Infection was also performed in the presence of monoclonal antibodies 4G2 against DENV-2 E protein, which were kindly donated by Dr. María Alba Loroño-Pino from the Laboratory of Arbovirology, Center of Regional Researches "Dr. Hideyo Noguchi”, Autonomous University of Yucatan, Mexico. Serial 4-fold dilutions of the antibodies were performed in DMEM (final concentrations $0.02-25 \mathrm{ng} / \mu \mathrm{L}$ ). Diluted antibody and DENV strains were mixed and incubated for $1 \mathrm{hr}$ at $37^{\circ} \mathrm{C}$ in gentle agitation. Virus-antibody complexes were inoculated in U937-DC-SIGN cells. After 1 $\mathrm{hr}$ of incubation, the inoculum was discarded, fresh medium was added and infected cell supernatants were collected at several times after infection to determine viral titer and cytokine concentrations.

\section{Virus titration in BHK-2I cells}

Supernatants of infected U937-DC-SIGN cells collected in each assay were unfrozen, 10-fold serial dilutions were prepared in DMEM and used to inoculate BHK-21 cells seeded in 24-well culture plates. After $1 \mathrm{hr}$ of incubation at $37^{\circ} \mathrm{C}$, viral inoculum was replaced with $1 \mathrm{~mL}$ of DMEM supplemented with $0.35 \%$ agarose and $2.5 \% \mathrm{FBS}$. Infected BHK-21 cells were incubated for $72 \mathrm{hrs}$ at $37^{\circ} \mathrm{C}$. After that, cultures were fixed with $10 \%$ trichloroacetic acid for 10 mins, gel was discarded and cells were stained with $1 \%$ crystal violet for 10 mins and washed. Viral titer was expressed as $\mathrm{PFU} / \mathrm{mL}$.

\section{Polyphenolic compounds}

Quercetin, fisetin, apigenin, rutin and resveratrol (at $\geq 95 \%$ purity) were purchased from Sigma-Aldrich (St Louis, MO, USA; Catalogue Nos.: Q4951, F4043, A3145,
R5143 and R5010, respectively). Curcumin was kindly donated by Dr. Dino Gnecco, from the Laboratory of Organic Chemistry of Autonomous University of Puebla, Mexico. It was extracted and purified from Curcuma longa; $>95 \%$ purity was corroborated by HPLC.

Each compound was dissolved in dimethylsulfoxide (DMSO) to obtain stock solutions at $100 \mathrm{mM}$ concentrations that were further dissolved in RPMI medium. Final DMSO concentration was less than $0.1 \%$.

\section{Toxicity assays}

Polyphenol cytotoxicity was tested on U937-DC-SIGN cells cultured in 96-well plates following the MTT colorimetric method. Briefly, 50,000 cells per well were incubated with several concentrations $(2.5-1,000 \mu \mathrm{M})$ of each polyphenolic compound for $72 \mathrm{hrs}$. After that, the medium was removed, cells were twice washed with PBS, $100 \mu \mathrm{L}$ of $0.5 \mathrm{mg} / \mathrm{ml}$ MTT was added into each well and incubated for $3 \mathrm{hrs}$ at $37^{\circ} \mathrm{C}$. After that, $100 \mu \mathrm{L}$ of $0.1 \%$ DMSO was added and the optical density was determined at $570 \mathrm{~nm}$. A standard curve was included with known amounts of untreated cells.

\section{Antiviral drug activity}

The effect of polyphenols on the replication of DENV in U937-DC-SIGN cells was tested using several noncytotoxic concentrations of each compound that were added to cell cultures at $1 \mathrm{hpi}$. Supernatants of infected and treated cells were collected at $6,12,24,48,72$ and $96 \mathrm{hpi}$, for the subsequent determination of virus titers and cytokine concentrations as mentioned.

\section{Cytokine detection}

The cytokine concentrations in the supernatants of infected and polyphenol treated cells were determined by ELISA using IL-6 (Cat. 430504), IL-10 (Cat. 430504), TNF- $\alpha$ (Cat. 430504), and IFN- $\gamma$ (Cat. 430504) kits following the producer's instructions (Biolegend, San Diego CA, USA).

\section{Statistical analysis}

Data analyses were performed and plotted in the GraphPad Prism software version 5.0 (GraphPad Software, La Jolla, CA, USA). Statistical analysis was performed using twoway ANOVA and Bonferroni test. Differences with $p<0.05$ were considered statistically significant. 


\section{Results}

\section{DENV infection increased in the presence of 4G2 antibody}

Macrophages U937-DC-SIGN showed a high infection efficiency, $>80 \%$ were infected. Viral titers produced by DENV-2 and DENV-3 in the presence or not of 4G2 antibody were compared. DENV-2 infection alone in U-937-DC-SIGN macrophages produced a mean viral titer of $19 \pm 1.8 \times 10^{3}$ PFU/mL at 72 hpi. Preincubation of DENV-2 with dilution 1:1024 $(0.09 \mathrm{ng} / \mu \mathrm{L})$ of $4 \mathrm{G} 2$ antibody increased viral titer to 45 $\pm 4.8 \times 10^{3} \mathrm{PFU} / \mathrm{mL}(p<0.001$, Figure 1B). Other antibody concentrations did not modify viral titer. DENV-3 was replicated more abundantly and produced a mean viral titer of 33 $\pm 1.7 \times 10^{3} \mathrm{PFU} / \mathrm{mL}$. DENV-3 titer increased to $71.7 \pm 3.3 \times 10^{3}$ PFU/mL $\left(p<0.01\right.$, Figure 1D) and $53 \pm 4.4 \times 10^{3} \mathrm{PFU} / \mathrm{mL}$ $(p<0.05$, not shown), in the presence of $4 \mathrm{G} 2$ antibody at 0.039 and $0.09 \mathrm{ng} / \mu \mathrm{L}$, respectively.

\section{Antiviral effect of polyphenolic compounds}

Six polyphenolic compounds were studied (Figure 1A), and they showed low toxicity for U937-DC-SIGN cells. Their half cytotoxic concentrations (CC50) were $136 \mu \mathrm{M}$ for curcumin, $159 \mu \mathrm{M}$ for fisetin, $180 \mu \mathrm{M}$ for resveratrol, 225 $\mu \mathrm{M}$ for apigenin, $340 \mu \mathrm{M}$ for quercetin and $501 \mu \mathrm{M}$ for rutin. In subsequent experiments, antiviral activities of polyphenolic compounds were tested at noncytotoxic concentrations.

Macrophages infected with DENV-2 or DENV-3 were treated with each polyphenol at $1 \mathrm{hr}$ after infection. Only quercetin and fisetin inhibited significantly DENV-2 infection. Treatment with $100 \mu \mathrm{M}$ quercetin inhibited DENV-2 infection alone or in the presence of $4 \mathrm{G} 2$ antibody $(0.7$ $\pm 0.1 \times 10^{3}$ and $3.5 \pm 1.5 \times 10^{3} \mathrm{PFU} / \mathrm{mL}, p<0.001$, Figure $1 \mathrm{~B}$ ). Treatment with $40 \mu \mathrm{M}$ Fisetin also inhibited DENV-2 infection alone or in the presence of $4 \mathrm{G} 2$ antibody $\left(2.5 \pm 1.1 \times 10^{3}\right.$
A

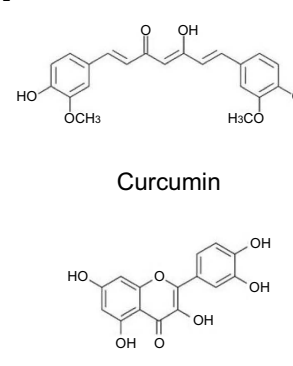

Quercetin

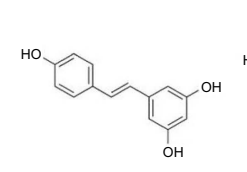

Resveratrol

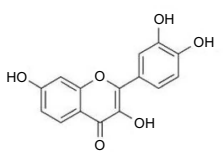

Fisetin
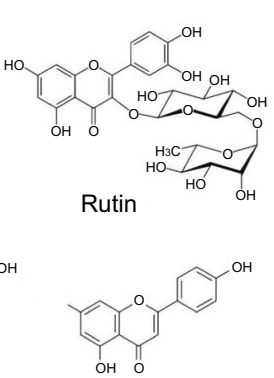

Apigenin
B

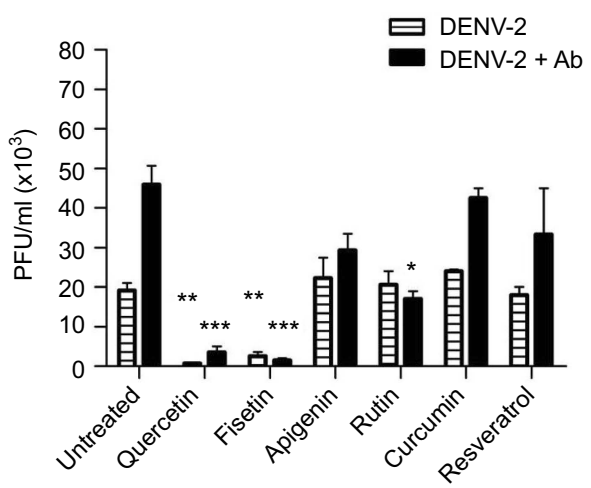

C

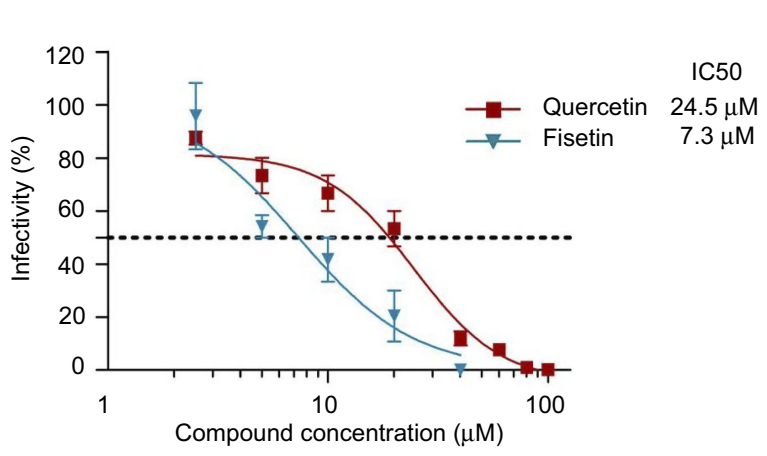

D

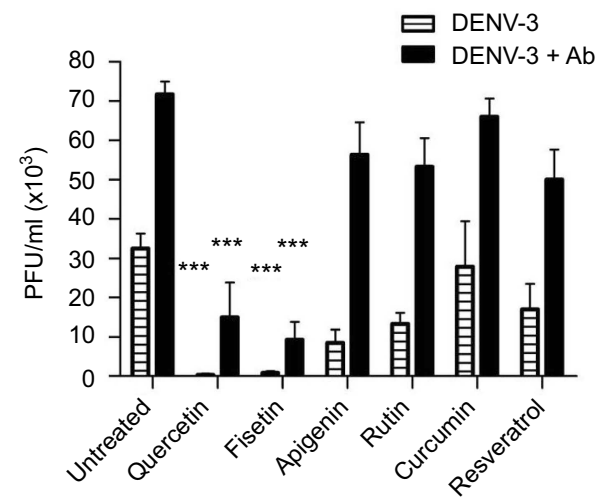

Figure I DENV infection alone or enhanced with 4G2 antibody was inhibited by polyphenols. (A) Molecular structure of polyphenolic compounds tested in this study. (B and D) Macrophages were infected with DENV-2 (B) or DENV-3 (D) at a MOI of I, alone or in the presence of 4G2 antibody (dilutions I:I024 for DENV-2 and I:256 for DENV-3 are shown). After I hr of infection, cells were treated with noncytotoxic concentrations of polyphenols: $20 \mu M$ curcumin, $100 \mu M$ quercetin, $100 \mu M$ resveratrol, 40 $\mu \mathrm{M}$ apigenin, $100 \mu \mathrm{M}$ rutin or $40 \mu \mathrm{M}$ fisetin. Cell supernatants were collected at $72 \mathrm{hrs}$ postinfection and viral titers (PFU/mL) were determined by plaque assay in BHK-2I cells. Untreated infected cells were included as controls. Bars represent average \pm SD of three independent experiments done by duplicate. Data were analyzed by one-way ANOVA with subsequent Bonferroni's test using GraphPad Prism 5.0. Asterisks represent statistical significance $(* p<0.05$, $* * p<0.01$, $* * * p<0.001)$ compared with the respective controls. (C) Doseantiviral response of fisetin and quercetin in macrophages infected with DENV-2. U937-DC-SIGN cells were infected with DENV-2 and then treated with different concentrations of fisetin $(2.5-40 \mu \mathrm{M})$ or quercetin $(2.5-100 \mu \mathrm{M})$. Supernatants were collected at 72 hpi and viral titers were determined by plaque assay as mentioned. The percentage of infection was calculated by comparing treated versus untreated cells, the inhibitory concentration (IC50) was calculated using GraphPad Prism 5.0. In both cases, data represent the average \pm SD of three independent experiments.

Abbreviations: DENV, dengue virus; MOI, multiplicity of infection; PFU, plague-forming unit. 
and $1.5 \pm 0.5 \times 10^{3} \mathrm{PFU} / \mathrm{mL}$, respectively, $p<0.01$, Figure $1 \mathrm{~B}$ ). Quercetin and fisetin half inhibitory concentrations (IC50) on DENV-2 infection were $24.5 \mu \mathrm{M}$ and $7.3 \mu \mathrm{M}$, respectively (Figure 1C). Their selectivity indices were 13.9 and 21.78 , respectively; this suggests that fisetin has a better antiviral activity than quercetin. Quercetin and fisetin also inhibited DENV-3 infection alone $\left(0.5 \pm 0.1 \times 10^{3}\right.$ and $0.8 \pm 0.4 \times 10^{3} \mathrm{PFU} /$ $\mathrm{mL}$, respectively, $p<0.001$ ) or in the presence of $4 \mathrm{G} 2$ antibody $\left(15 \pm 8.8 \times 10^{3}\right.$ and $9.3 \pm 4.5 \times 10^{3} \mathrm{PFU} / \mathrm{mL}$, respectively, $p<0.001$, Figure 1D).

Curcumin $(20 \mu \mathrm{M})$, resveratrol $(100 \mu \mathrm{M})$, apigenin $(40$ $\mu \mathrm{M})$ or rutin $(100 \mu \mathrm{M})$ did not reduce significantly DENV-2 infection alone. Rutin reduced partially DENV-2 infection in the presence of $4 \mathrm{G} 2$ antibody $\left(17 \pm 2 \times 10^{3} \mathrm{PFU} / \mathrm{mL}, p<0.05\right.$, Figure 1B). Apigenin, rutin and resveratrol produced some reduction in DENV-3 infection alone $\left(17 \pm 6.5 \times 10^{3}, 8.5\right.$ $\pm 3.3 \times 10^{3}$ and $13.3 \pm 2.9 \times 10^{3} \mathrm{PFU} / \mathrm{mL}$, respectively, $p<0.01$, Figure 1D), but did not affect significantly DENV-3 infection in the presence of $4 \mathrm{G} 2$ antibody. Higher concentrations of these compounds were cytotoxic for macrophages; therefore, they were not further analyzed.

\section{Kinetics of cytokine secretion in DENV-2-infected monocytes and macrophages}

All the results concerning cytokine secretion are summarized in Table 1. Uninfected monocytes produced low amounts of IL-6 $(8 \pm 2 \mathrm{pg} / \mathrm{mL})$, this increased 10-fold after the infection with DENV-2 (83 $\pm 6 \mathrm{pg} / \mathrm{mL}$, Figure $2 \mathrm{~A})$. Uninfected macrophages produced abundant IL-6 $(638.5 \pm 64 \mathrm{pg} / \mathrm{mL}$ at $48 \mathrm{hrs}$ after PMA differentiation). IL-6 augmented considerably after DENV-2 infection. Indeed, IL-6 was abundantly produced from 12 to $96 \mathrm{hpi}$, the maximal peak was observed at $48 \mathrm{hrs}$ after infection $(954.2 \pm 147.9 \mathrm{pg} / \mathrm{mL}, p<0.001$, Figure $2 \mathrm{~A})$.

The amount of TNF- $\alpha$ was under the test detection limits $(<3 \mathrm{pg} / \mathrm{mL})$ in uninfected monocytes but showed a slight increase after DENV-2 infection $(5 \pm 1 \mathrm{pg} / \mathrm{mL}$ at 24 hpi, Figure 2B). High production of TNF- $\alpha$ was observed after PMA differentiation (233.1 \pm 23 at $24 \mathrm{hrs})$, but it was significantly higher after DENV-2 infection, showing the maximal peak from 12 to $24 \mathrm{hpi}(377.7 \pm 9.6 \mathrm{pg} / \mathrm{mL}$, $p<0.001$, Figure 2B).

Uninfected monocytes produced IL-10 $(37.7 \pm 4 \mathrm{pg} / \mathrm{mL})$ and showed a small increase after DENV-2 infection (52.8 $\pm 7 \mathrm{pg} / \mathrm{mL}$ at $24 \mathrm{hpi}$, Figure 2C). Differentiation with PMA triplicated the secretion of IL-10 in macrophages (157.6 \pm 19.4 $\mathrm{pg} / \mathrm{mL}$ at $24 \mathrm{hrs}$ ), but this was not significantly affected after DENV-2 infection (165.7 $29.8 \mathrm{pg} / \mathrm{mL}$ at $24 \mathrm{hpi}$, Figure $2 \mathrm{C})$.

The concentrations of IFN- $\gamma$ in uninfected monocytes were under the test detection limits $(<3 \mathrm{pg} / \mathrm{mL})$, and DENV-2 infection induced a small increase in those cells $(8 \pm 1.4 \mathrm{pg} / \mathrm{mL}$ at $24 \mathrm{hpi}$, Figure 2D). PMA induced IFN- $\gamma$ secretion in uninfected macrophages $(61 \pm 9 \mathrm{pg} / \mathrm{mL}$ at 12 hrs). IFN- $\gamma$ was $>2$-fold increased after DENV-2 infection (155 $\pm 18 \mathrm{pg} / \mathrm{mL}$ at $24 \mathrm{hpi}$, Figure 2D).

Assays to search for IL-12 were performed but all of them resulted under detection limits.

\section{Enhancing antibodies modify the profiles of cytokine secretion}

DENV-2 infection in the presence of 4G2 antibody induced notable changes in cytokine profiles: IL-6 showed a remarkable low amount $(103.9 \pm 25.3 \mathrm{pg} / \mathrm{mL}$ at $24 \mathrm{hpi})$ compared to cells infected without 4G2 antibody (Figure 3A). In contrast, high amount of TNF- $\alpha$ was found in the presence of 4G2 antibody, showing the maximal peak at 24 hpi (1173.8 $\pm 54.4 \mathrm{pg} / \mathrm{mL}$, Figure 3B). Nonsignificant reduction in IL-10

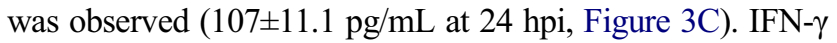
secretion started early in cells infected in the presence of 4G2 antibody (maximal peak $192.5 \pm 13.3 \mathrm{pg} / \mathrm{mL}$ at $12 \mathrm{hpi}$, Figure 3D).

\section{Cytokine secretion induced by DENV-3 diverged from that of DENV-2}

Production of IL-6 was observed in DENV-3-infected cells $(89.4 \pm 5.4 \mathrm{pg} / \mathrm{mL}$ at $24 \mathrm{hpi}$, Figure $4 \mathrm{~A})$, but the maximal peak was 10 -fold smaller than that induced by DENV-2 infection (Figure 3A). A similar amount of IL-6 was produced by cells infected with DENV-3 in the presence of $4 \mathrm{G} 2$ antibody $(79.5 \pm 2.5 \mathrm{pg} / \mathrm{mL}$ at $24 \mathrm{hpi}$, Figure $4 \mathrm{~A})$.

Significant production of TNF- $\alpha$ was observed from 12 to $36 \mathrm{hpi}$ in DENV-3-infected cells (maximal peak $365 \pm 35$ $\mathrm{pg} / \mathrm{mL}$ at $24 \mathrm{hpi}, p<0.001)$. In the presence of $4 \mathrm{G} 2$ antibody, TNF- $\alpha$ secretion was duplicated (maximal peak $789.5 \pm 52.5 \mathrm{pg} / \mathrm{mL}$ at $48 \mathrm{hpi}, p<0.001$, Figure $4 \mathrm{~B}$ ).

IL-10 secretion induced by DENV-3 $(57 \pm 12 \mathrm{pg} / \mathrm{mL}$ at 24 hpi) was comparable to that of uninfected control, but increased significantly in the presence of $4 \mathrm{G} 2$ antibody at 24 hpi $(93.4 \pm 12.1 \mathrm{pg} / \mathrm{ml} ; p<0.001$; Figure $4 \mathrm{C})$. IFN- $\gamma$ secretion was notably induced by DENV-3 from 12 to 24 hpi and increased in the presence of 4G2 antibody (183.3 $\pm 14 \mathrm{pg} / \mathrm{ml}$ at $24 \mathrm{hpi}$; Figure 4D). 
Table I Cytokine production in U937-DC-SIGN cells at the time of maximal secretion

\begin{tabular}{|c|c|c|c|c|}
\hline Cell treatment or infection & IL-6 (pg/mL) & TNF- $\alpha(p g / m L)$ & IFN- $\gamma(\mathrm{pg} / \mathrm{mL})$ & IL-I 0 (pg/mL) \\
\hline \multicolumn{5}{|l|}{ Monocytes } \\
\hline Not infected & $8 \pm 1$ & $1.8 \pm 0.5$ & $0.5 \pm 0.1$ & $37.7 \pm 4$ \\
\hline DENV-2 infected & $83.4 \pm 6$ & $5 \pm 0.7$ & $8 \pm 1.4$ & $52.8 \pm 7$ \\
\hline \multicolumn{5}{|l|}{ Macrophages } \\
\hline Not infected & $638.5 \pm 64 *$ & $233.1 \pm 22.9$ & $59.5 \pm 0.5$ & $157.6 \pm 19.4$ \\
\hline \multicolumn{5}{|l|}{ Not infected, treated with: } \\
\hline Quercetin & $125.1 \pm 4.5$ & $75.5 \pm 15.4$ & $5.3 \pm 3.5$ & $77.5 \pm 12.5$ \\
\hline Fisetin & $147.6 \pm 6$ & $30.8 \pm 24.8$ & $2.8 \pm 2.8$ & $115.9 \pm 6.1$ \\
\hline Apigenin & $204.6 \pm 66$ & $223.3 \pm 24.7$ & 0 & $164.9 \pm 8.6$ \\
\hline Rutin & $396 \pm 21.2$ & $247.6 \pm 23.32$ & 0 & $141.5 \pm 19.2$ \\
\hline Curcumin & $381.6 \pm 66$ & $283.9 \pm 53.3$ & 0 & $120.3 \pm 10.1$ \\
\hline Resveratrol & $417.7 \pm 18.5$ & $204.2 \pm 39.8$ & 0 & $132.4 \pm 4.2$ \\
\hline DENV-2 infected & $954.2 \pm 60.4^{*}$ & $377.7 \pm 9.6$ & $155 \pm 10$ & $165.7 \pm 29.9$ \\
\hline \multicolumn{5}{|c|}{ DENV-2 infected, treated with: } \\
\hline Quercetin & $19 \pm 3$ & $84.6 \pm 29.6$ & $29.6 \pm 11.3$ & $7.1 \pm 2.4$ \\
\hline Fisetin & $168.1 \pm 31.9$ & $93.5 \pm 6.5$ & $19.4 \pm 0.5$ & $22.8 \pm 6.8$ \\
\hline Apigenin & $611 \pm 3$ & $407.5 \pm 48.5$ & $33.0 \pm 14$ & $4.5 \pm 4.5$ \\
\hline Rutin & $694 \pm 54$ & $422.6 \pm 43.3$ & $30 \pm 7$ & $17.6 \pm 2.4$ \\
\hline Curcumin & $169 \pm 5$ & $285.9 \pm 11.7$ & $75 \pm 15$ & $21 \pm 10$ \\
\hline Resveratrol & $623 \pm 7$ & $337.2 \pm 10.4$ & $108.5 \pm 18.5$ & $12.7 \pm 2.3$ \\
\hline DENV-2+ Ab infected & $103.9 \pm 25.3$ & $1173.8 \pm 54.4$ & $192.5 \pm 13.3^{* *}$ & $107 \pm 13.1$ \\
\hline \multicolumn{5}{|c|}{ DENV-2+ Ab infected, treated with: } \\
\hline Quercetin & $49.2 \pm 11.1$ & $70.6 \pm 10$ & $145.8 \pm 12.5$ & $3 \pm 1$ \\
\hline Fisetin & $41.7 \pm 11.6$ & $177.5 \pm 5.6$ & $|23.8 \pm 1| .3$ & $26 \pm 4$ \\
\hline Apigenin & $50.1 \pm 11.1$ & $126.3 \pm 19.4$ & $115.9 \pm 16.7$ & $23 \pm 6$ \\
\hline Rutin & $80.2 \pm 16.1$ & $865.6 \pm 13.8$ & $118.8 \pm 14.5$ & $92.2 \pm 7.3$ \\
\hline Curcumin & $78.6 \pm 20.3$ & $1275.0 \pm 39.4$ & $134.2 \pm 25.9$ & $107.1 \pm 10.5$ \\
\hline Resveratrol & $51.1 \pm 11.3$ & $160.6 \pm 21$ & $143.8 \pm 12.1$ & $13.6 \pm 4.9$ \\
\hline DENV-3 infected & $89.4 \pm 5.4$ & $365 \pm 33$ & $106 \pm 15^{* *}$ & $57 \pm 12$ \\
\hline \multicolumn{5}{|l|}{ DENV-3 infected, treated with: } \\
\hline Quercetin & $8.7 \pm 2.3$ & $91.0 \pm 16$ & $98.3 \pm 14$ & $18.5 \pm 3.5$ \\
\hline Fisetin & $31.7 \pm 9.2$ & $26.3 \pm 3.2$ & $137.8 \pm 25.5$ & $13.8 \pm 2.9$ \\
\hline Apigenin & $62.4 \pm 6$ & $4 \mid 2.5 \pm 28$ & $88.5 \pm \mid 4.1$ & $34.9 \pm 4.3$ \\
\hline Rutin & $75.3 \pm 8.1$ & $328 \pm 23.8$ & $95.3 \pm 5.6$ & $22.9 \pm 3.3$ \\
\hline Curcumin & $44.8 \pm 7.2$ & $243 \pm 13.2$ & $79.4 \pm 8.4$ & $33.4 \pm 5.1$ \\
\hline Resveratrol & $78.2 \pm 4.3$ & $348 \pm 18.2$ & $102.2 \pm 4$ & $29.8 \pm 1.5$ \\
\hline DENV-3+ Ab infected & $79.5 \pm 7.5$ & $789.5 \pm 52.5^{*}$ & $183.3 \pm 14$ & $93.4 \pm 12.1$ \\
\hline \multicolumn{5}{|c|}{ DENV-3+ Ab infected, treated with: } \\
\hline Quercetin & $11.2 \pm 0.7$ & $260.0 \pm 60$ & $98.5 \pm 11.5$ & $22.5 \pm 4.5$ \\
\hline Fisetin & $58 \pm 4.5$ & $24.5 \pm 1.5$ & $144.8 \pm 5.5$ & $10.5 \pm 3.4$ \\
\hline Apigenin & $48 \pm 4.4$ & $383 \pm 33.3$ & $152.1 \pm 13.3$ & $74.8 \pm 8.3$ \\
\hline Rutin & $66 \pm 3.8$ & $603 \pm 28.4$ & $|62 \pm 2|$ & $88.9 \pm 7.3$ \\
\hline Curcumin & $43 \pm 5.7$ & $743 \pm 20.4$ & $102 \pm 6.8$ & $79.4 \pm 19.4$ \\
\hline Resveratrol & $73.8 \pm 6.3$ & $683 \pm 16.3$ & $123.2 \pm 15.3$ & $49.5 \pm 6.2$ \\
\hline
\end{tabular}

Notes: Maximal cytokine concentration in cell media at $24 \mathrm{hrs}$ after infection, except when it is indicated $* 48$ hrs or $* * 12$ hrs. Values represent the average of three experiments plus standard deviation. Ab represents infections done with virus-antibody complexes.

Abbreviation: DENV, dengue virus. 

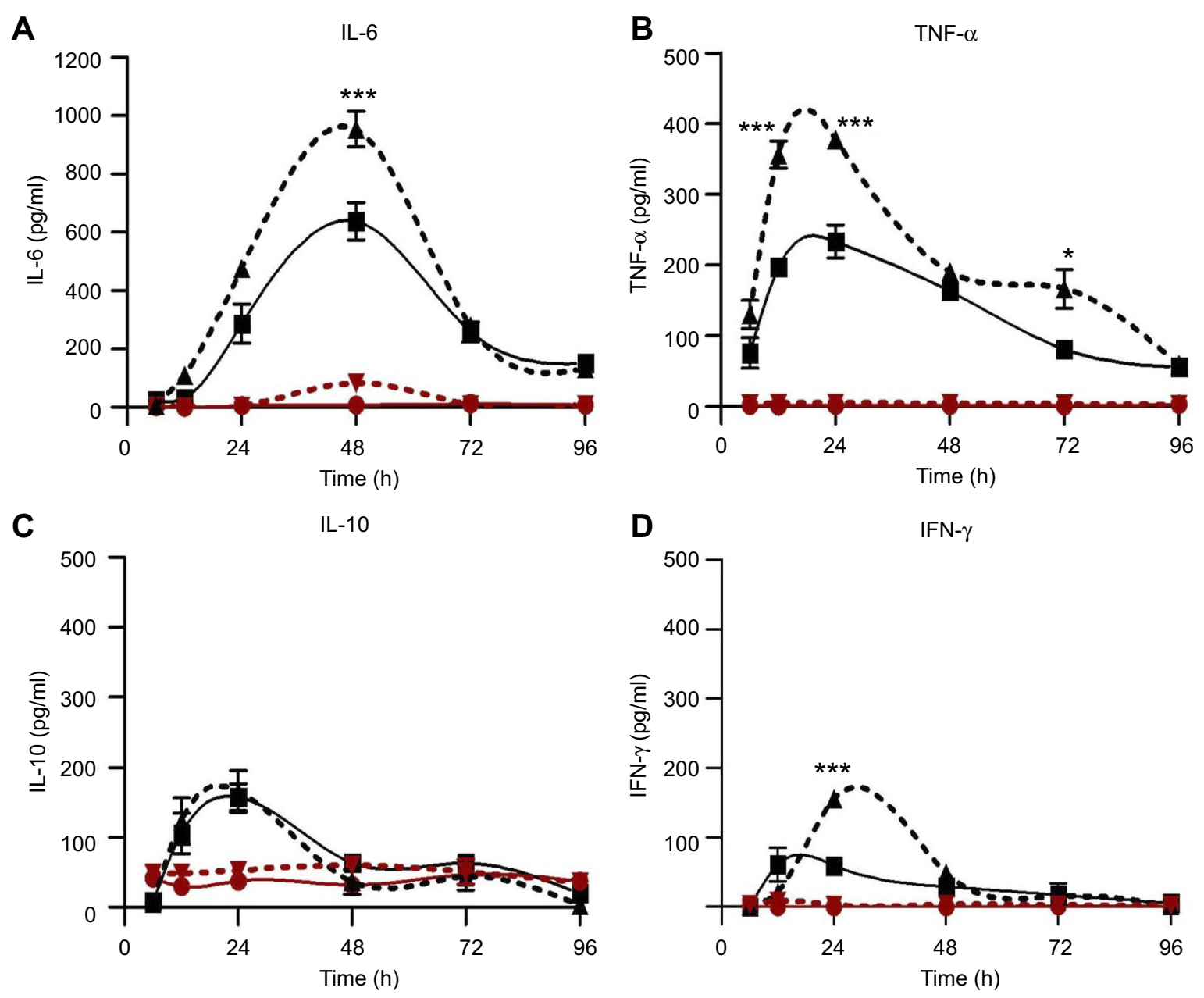

D

IFN- $\gamma$

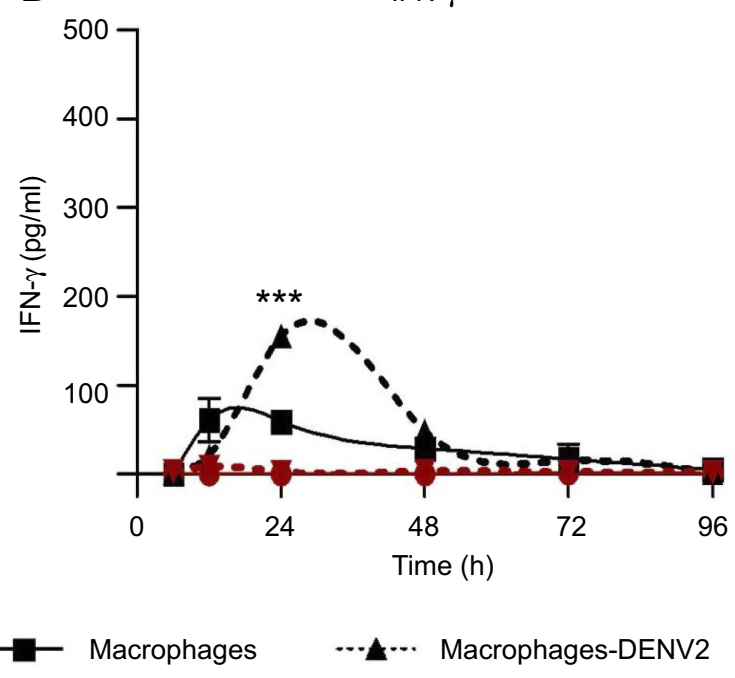

Figure 2 Cytokine production in monocytes and macrophages. Kinetics of cytokine production was determined in U937-DC-SIGN monocytes and macrophages either uninfected or infected with DENV-2 at a MOI=I. Cell supernatant was collected at different times (6, I2, 24, 48, 72 and $96 \mathrm{hrs}$ ) and the concentration of IL-6 (A), TNF- $\boldsymbol{\alpha}$ (B), IL-I0 (C) and IFN- $\gamma$ (D) was determined by ELISA. Data were analyzed by two-way ANOVA with subsequent Bonferroni's test using GraphPad Prism 5.0. Nonlinear regression analysis was performed to obtain trend lines. Asterisks represent statistical significance $(* p<0.05 ; * * * p<0.001)$ between uninfected and DENV-2-infected macrophages.

Abbreviations: DENV, dengue virus; MOI, multiplicity of infection.

\section{Polyphenols modulate cytokine secretion in DENV-2 infected cells}

The profiles of cytokines produced by DENV-2-infected macrophages (described in Section 3.3) were used as comparative controls (Figure 5A) to determine the changes induced after polyphenol treatment. IL-6 was downregulated by quercetin $(19 \pm 3 \mathrm{pg} / \mathrm{ml}, p<0.001$; Figure $5 \mathrm{~B})$, fisetin (168.1 $\pm 31.9 \mathrm{pg} / \mathrm{mL}, p<0.001$, Figure 5C) and curcumin $(169 \pm 5 \mathrm{pg} / \mathrm{mL}$, Figure S1Q). Treatment with apigenin, rutin or resveratrol reduced less than $30 \%$ IL-6 secretion compared to untreated DENV-2-infected cells.

TNF- $\alpha$ was down-regulated by quercetin $(84.6 \pm 29.6$ $\mathrm{pg} / \mathrm{mL}$ at $24 \mathrm{hpi}, p<0.001$, Figure $5 \mathrm{~B})$ and partially by fisetin $(93.5 \pm 6.5 \mathrm{pg} / \mathrm{mL}$ at $24 \mathrm{hpi}, p<0.001$, Figure $5 \mathrm{C})$ and curcumin (Figure S1R). No other compound reduced significantly TNF- $\alpha$ secretion.

IL-10 was down-regulated by fisetin, apigenin and resveratrol (Figure S1G, K and W); and IFN- $\gamma$ by fisetin and rutin $(31.7 \pm 2.4$ and $47 \pm 10 \mathrm{pg} / \mathrm{mL}$, respectively, Figure $\mathrm{S} 1 \mathrm{H}$ and $\mathrm{P})$. Other compounds partially modify the kinetics of IFN- $\gamma$.

Half effective concentrations (EC50) were calculated for compounds that modulate cytokine secretion at the times of maximal production. Fisetin EC50 values were $11.4 \mu \mathrm{M}$ for IL-6, 3.1 $\mu \mathrm{M}$ for TNF- $\alpha, 3.3 \mu \mathrm{M}$ for IFN- $\gamma$ and $3.1 \mu \mathrm{M}$ for IL-10. Quercetin EC50 values were $16.9 \mu \mathrm{M}$ for IL-6, $20.5 \mu \mathrm{M}$ for TNF- $\alpha,<2.5 \mu \mathrm{M}$ for IFN- $\gamma$ and $11.9 \mu \mathrm{M}$ for IL-10. These results showed that 

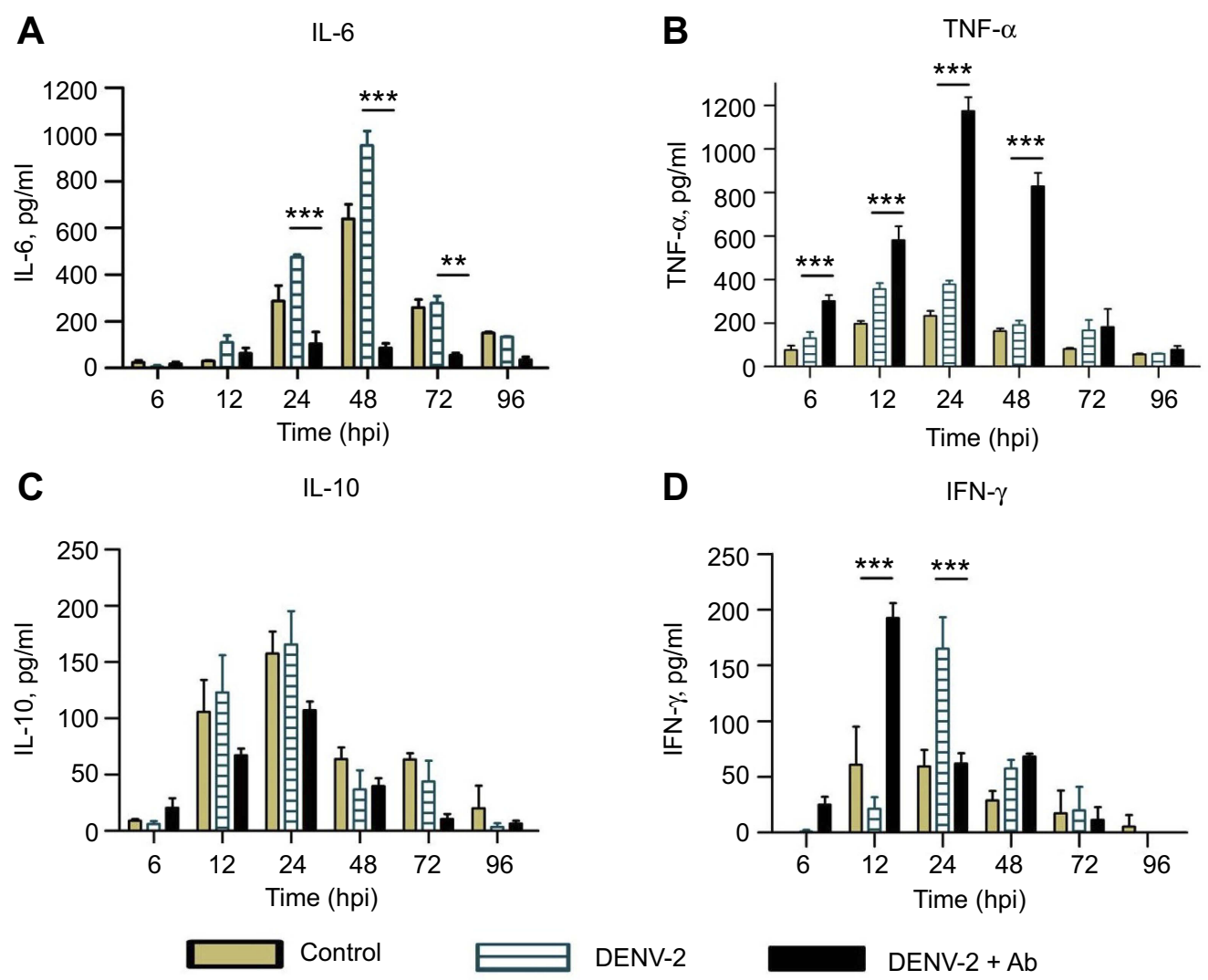

Figure 3 Cytokine secretion in U937-DC-SIGN cells infected with DENV-2. Kinetics of cytokine secretion was analyzed in macrophages. Controls correspond to PMA differentiated but not infected cells. DENV-2 represents infection without antibody. DENV-2 ADE indicates infection done in the presence of $4 G 2$ antibody at I:I024 dilution. Cell supernatants were collected at $6,12,24,48,72$ and 96 hpi and the concentrations of IL-6 (A), TNF- $\alpha$ (B), IL-I0 (C) and IFN- $\gamma$ (D) were determined by ELISA. Data were analyzed by two-way ANOVA with subsequent Bonferroni's test using GraphPad Prism 5.0. Asterisks represent statistical significance $(* * p<0.0$ I; $* * * p<0.00 \mathrm{I})$ between DENV-2 and DENV-2-ADE.

Abbreviation: DENV, dengue virus.

fisetin has better immunomodulatory potential than quercetin.

\section{Modulation of cytokines in DENV-2 infection enhanced with antibody}

TNF- $\alpha$ secretion induced by DENV-2 in the presence of $4 \mathrm{G} 2$ antibody (Figure 5D) was notably down-regulated by quercetin $(70.6 \pm 10 \mathrm{pg} / \mathrm{mL}$, Figure $5 \mathrm{E})$, fisetin $(177.5 \pm 5.6 \mathrm{pg} / \mathrm{mL}$, Figure 5F), apigenin $(166.3 \pm 18.6 \mathrm{pg} / \mathrm{mL}$, Figure S2J) and resveratrol (192.8 $\pm 4.4 \mathrm{pg} / \mathrm{mL}, p<0.001$, Figure $\mathrm{S} 2 \mathrm{~V})$.

Quercetin, fisetin, apigenin and resveratrol also reduced the secretion of IL-10 in cells infected with DENV-2 and 4G2 antibody (Figure S2C, G, K and W). Other changes in cytokine secretion after polyphenol treatments were not significant.

\section{Polyphenols modulate cytokine production in DENV-3-infected cells}

DENV-3 infection alone induced high amounts of TNF$\alpha$ (Figure 6A) and it was duplicated in the presence of
4G2 antibody (Figure 6D). Quercetin down-regulated TNF- $\alpha$ produced by DENV-3-infected cells either in the absence $(91 \pm 16 \mathrm{pg} / \mathrm{mL}$, Figure $6 \mathrm{~B})$ or in the presence of 4G2 antibody $(260 \pm 60 \mathrm{pg} / \mathrm{mL}$, Figure $6 \mathrm{E})$. Fisetin reduced temporally TNF- $\alpha$ in DENV-3-infected cells (Figure 6C) but inhibited $90 \%$ of TNF- $\alpha$ induced by the presence of $4 \mathrm{G} 2$ antibody $(149 \pm 54 \mathrm{pg} / \mathrm{mL}$, Figures $6 \mathrm{~F}$ and $\mathrm{S} 4 \mathrm{~F}$ ).

Although the secretion of IL-6 was low in cells infected with DENV-3 $(89.4 \pm 5.4 \mathrm{pg} / \mathrm{mL})$, it was reduced by quercetin and fisetin $(21.5 \pm 9.2$ and $31.7 \pm 9.2 \mathrm{pg} / \mathrm{mL}$, respectively, Figure S3A and E). In the presence of $4 \mathrm{G} 2$ antibody, only quercetin reduces IL-6 secretion (30.2 \pm 5.4 $\mathrm{pg} / \mathrm{mL}$, Figure S4A).

Quercetin and fisetin reduce significantly IL-10 in cells both in normal or in enhanced DENV-3 infection (Figures S3 and S4C and G). Only fisetin induced an increase in the secretion of IFN- $\gamma$ in cells infected with DENV-3 (Figure S3H). No other changes in cytokines were statistically significant. 
A

IL-6

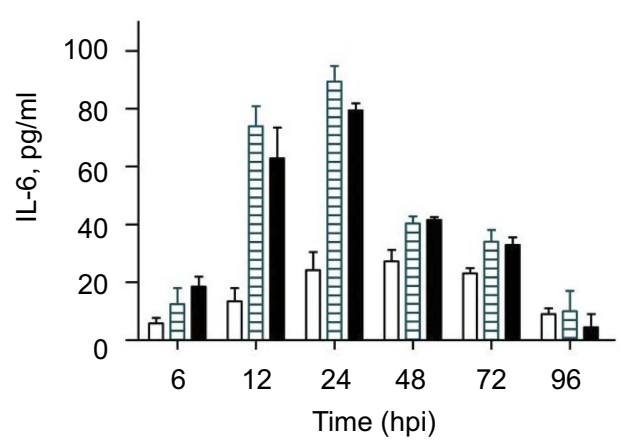

C

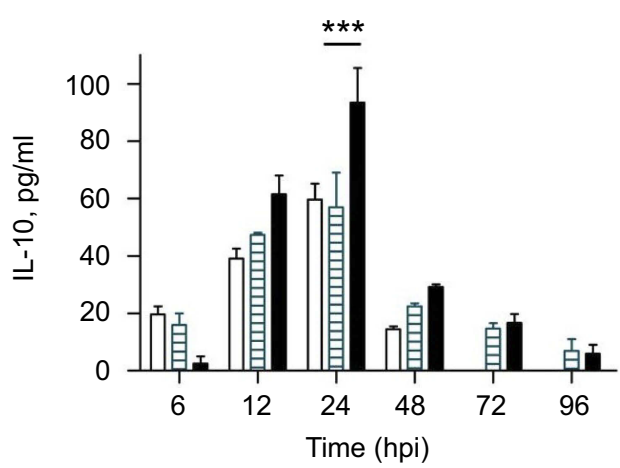

B TNF- $\alpha$

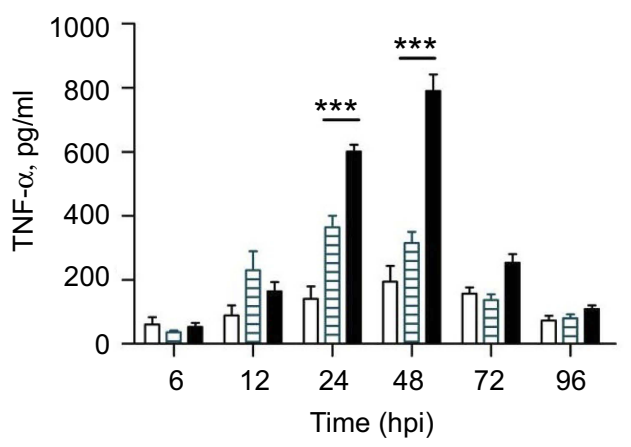

D IFN- $\gamma$

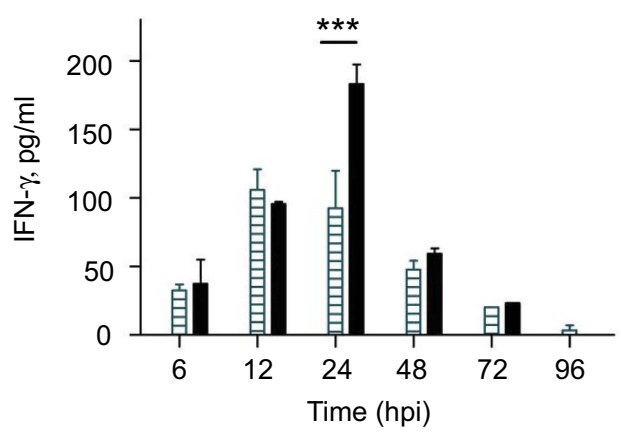

Control

DENV-3

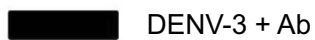

Figure 4 Cytokine secretion in U937-DC-SIGN cells infected with DENV-3. Kinetics of cytokine secretion was analyzed in macrophages. Controls correspond to PMA differentiated but not infected cells. DENV-3 represents infection without antibody. DENV-3 ADE indicates infection done in the presence of $4 \mathrm{G} 2$ antibody at I:256 dilution. Cell supernatants were collected at 6, 12, 24, 48, 72 and 96 hpi and the concentrations of IL-6 (A), TNF- $\alpha$ (B), IL-I0 (C) and IFN- $\gamma$ (D) were determined by ELISA. Data were analyzed by two-way ANOVA with subsequent Bonferroni's test using GraphPad Prism 5.0. Asterisks represent statistical significance (*** $p<0.00 \mathrm{I})$ between DENV-3 and DENV-3-ADE.

Abbreviation: DENV, dengue virus.

\section{Discussion}

There is an unmet need for specific and effective drugs against dengue infection, particularly for the treatment of severe cases. Our study focused on the testing of compounds with both antiviral and immunomodulatory properties because the immune response is involved in severe dengue pathogenesis. ${ }^{7,8,10-17}$ It has been hypothesized that heterotypic non-neutralizing antibodies induce ADE of infection, which during secondary infections increase the entry of virus particles into phagocytic cells, which produce an array of proinflammatory cytokines. ${ }^{28}$

We tested the antiviral effect of polyphenols in macrophages infected with DENV serotypes 2 and 3 either enhanced or not with antibodies. DENV-2 and DENV-3 normal infections (without enhancing antibodies) were completely inhibited by quercetin and fisetin but not by any other compound. Then, we tested if these compounds have antiviral effects on enhanced infection. Again, quercetin and fisetin have antiviral activity on DENV-2 and DENV-3 enhanced infection. It is important to note that although viral titers were higher in the enhanced infection, the inhibitory effect was reached using the same concentrations of quercetin $(100 \mu \mathrm{M})$ and fisetin $(40 \mu \mathrm{M})$ that were used to inhibit normal infection.

While normal infection with DENV-2 and DENV-3 was completely inhibited with quercetin and fisetin, some inhibition of DENV-3 was also observed with apigenin and rutin (Figure 1D). In addition, enhanced DENV-3 infection presented some grade of resistance to quercetin and fisetin treatment, amounts that inhibit completely DENV-2 were not totally effective on DENV-3. An explanation is that DENV-3 replicates more abundantly than DENV-2 (70 vs $48 \times 10^{3} \mathrm{PFU} / \mathrm{mL}$ ). Another explanation could be that fine 

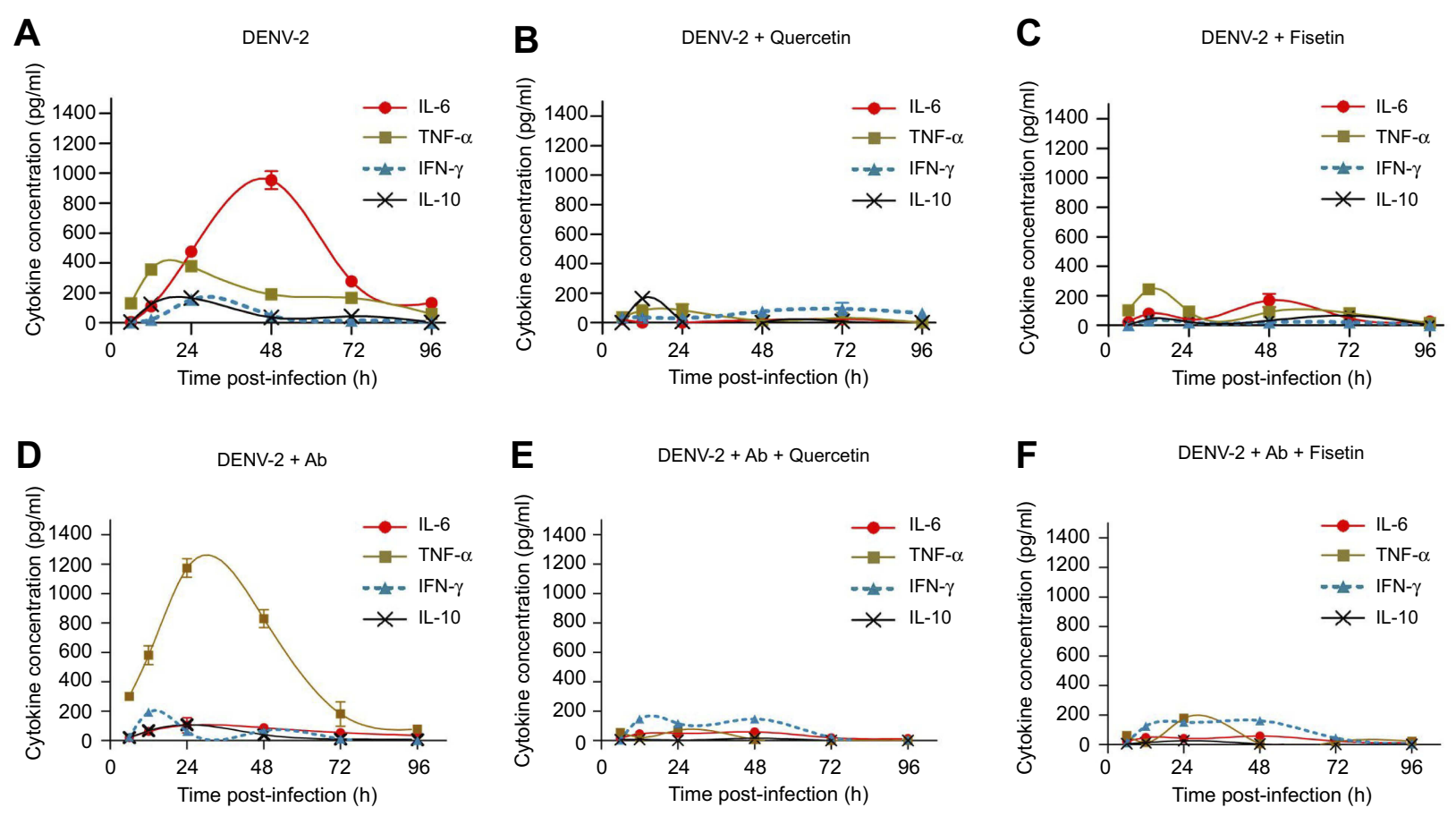

Figure 5 Effect of quercetin and fisetin on macrophages infected with DENV-2. Macrophages were infected with DENV-2 at a MOI of I (A-C) or with mixtures of DENV-2 and 4G2 antibody (ADE) at I:1024 dilution (D-F). Viral inoculum was discarded after I hr of infection and fresh medium was added with $100 \mu M$ of quercetin or $40 \mu M$ of fisetin. Untreated infected macrophages were included for comparison (A and $\mathbf{D})$. Cell supernatants were collected at different times postinfection and the concentrations of IL-6, TNF- $\boldsymbol{\alpha}$, IL-10 and IFN- $\gamma$ were determined by ELISA. Data represent average \pm SD of two independent and duplicated experiments; nonlinear regression analysis was performed using GraphPad Prism 5.0 to obtain trend lines.

Abbreviations: DENV, dengue virus; MOI, multiplicity of infection.
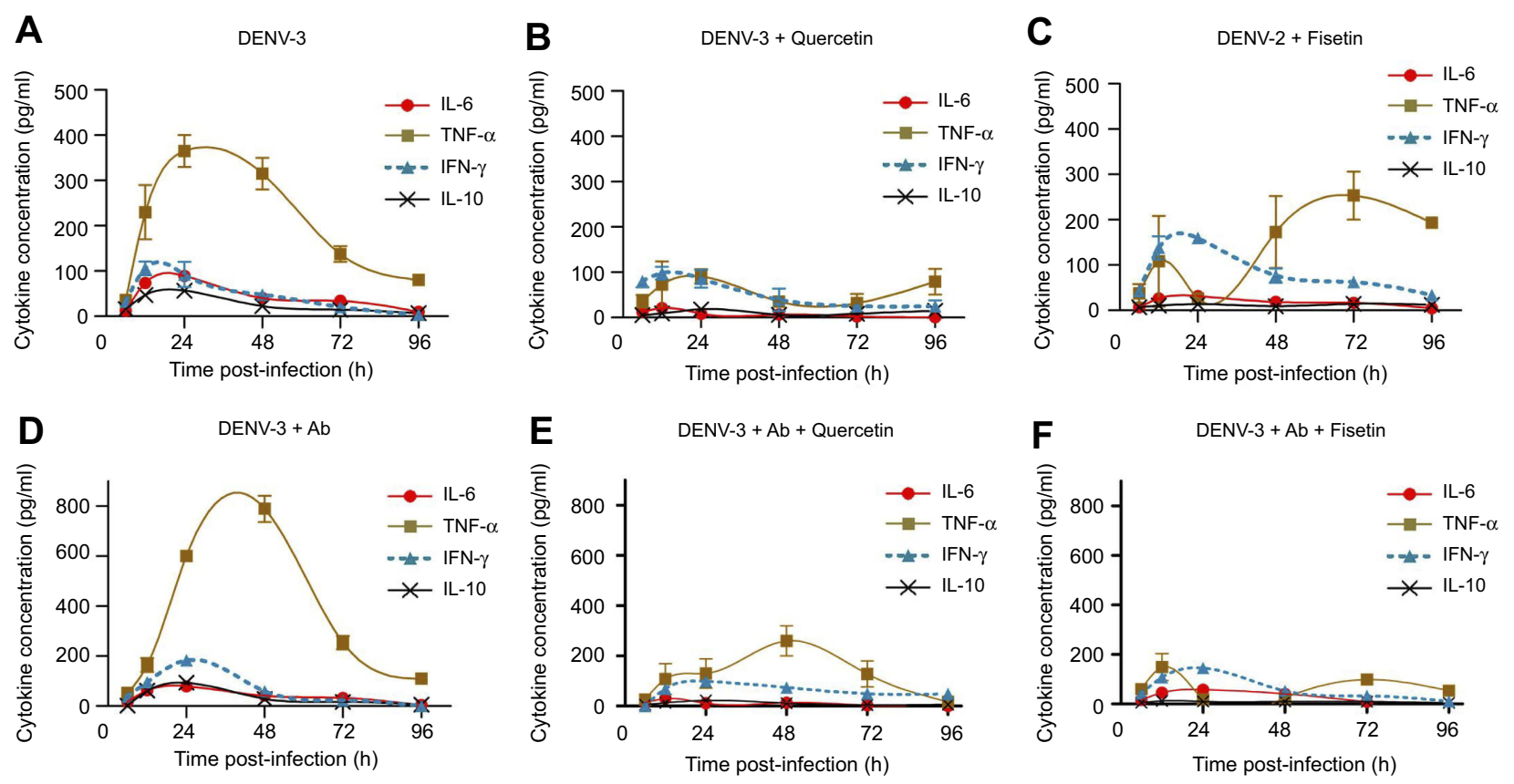

Figure 6 Effect of quercetin and fisetin on macrophages infected with DENV-3. Macrophages were infected with DENV-3 at a MOI of I (A-C) or with mixtures of DENV-3 and 4G2 antibody (ADE) at I:256 dilution (D-F). Viral inoculum was discarded after I hr of infection and fresh medium was added with $100 \mu M$ of quercetin or $40 \mu M$ of fisetin. Untreated infected macrophages were included for comparison (A and D). Cell supernatants were collected at different times postinfection and the concentrations of IL-6, TNF- $\alpha$, IL-10 and IFN- $\gamma$ were determined by ELISA. Data represent average \pm SD of two independent and duplicated experiments; nonlinear regression analysis was performed using GraphPad Prism 5.0 to obtain trend lines.

Abbreviations: DENV, dengue virus; $\mathrm{MOI}$, multiplicity of infection. 
structural differences between DENV serotypes affect the virus sensitivity and response to treatment; this is probable if the antiviral compound has a direct interaction with viral molecules. Quercetin and fisetin can exert antiviral effects through several mechanisms. In silico predictions indicate that quercetin and fisetin interact with $\mathrm{E},{ }^{29} \mathrm{NS} 1,{ }^{30} \mathrm{NS} 3^{31}$ and $\mathrm{NS}^{31,32}$ proteins; therefore, they could inhibit a different process of the viral replicative cycle. Also, quercetin and fisetin act directly on the cells, modifying signaling pathways involved in innate response. Therefore, treated cells increase the capacity to start defense mechanisms to avoid virus replication. Some studies showed that quercetin induces the reactivation of type 1 IFN-mediated JAKSTAT pathway ${ }^{33}$ triggering the transcription of genes involved in the antiviral response. It is well known that DENV blocks JAK-STAT pathway by several ways: 1) targeting STAT2 protein for degradation in the proteasome; ${ }^{34}$ 2) retaining phosphorylated-STAT1 in the cytoplasm of infected cells, this avoids nuclear translocation and transcription of antiviral genes; ${ }^{35}$ 3) inducing overexpression of suppressors of cytokine signaling 1 and $3^{17,35-37}$ and tyrosine phosphatases that down-regulate the antiviral response. Nonetheless, there is evidence that quercetin restores the innate response at least by modulating the expression of SOCS proteins $^{38}$ and SHP-2 phosphatase. $^{33}$

The other crucial part of our study was the search for immunomodulatory properties of polyphenols. At respect, monocytes, macrophages and dendritic cells are the main targets of DENV infection. ${ }^{39}$ These cells participate in phagocytosis of infectious agents, antigen processing and presentation to $\mathrm{T}$ cells, and they also orchestrate inflammation by secreting cytokines and other soluble factors. Phagocytic cells are susceptible to dengue infection because they express receptors used for virus attachment and entry such as the C-type lectins: CLEC5A, ${ }^{40,41}$ mannose receptor $(\mathrm{CD} 206)^{42}$ and DC-SIGN (dendritic cell-specific intercellular adhesion molecule-3-grabbing non-integrin, also known as CD209). ${ }^{43,44}$ Phagocytic cells also express Fc gamma receptors $(\mathrm{Fc} \gamma \mathrm{R})$ type I involved in the recognition of the Fc portion of immunoglobulins, which allowed increasing entry of nonneutralized virus particles. ${ }^{45}$ It was recently acknowledged that DC-SIGN is a type II Fc $\gamma \mathrm{R}$ involved in the recognition of the glycans joined to the Fc region of immunoglobulins. ${ }^{46}$ In our study, we used U937-DC-SIGN cells, because they are highly susceptible to DENV infection, possess Fc $\gamma \mathrm{R}$ to test $\mathrm{ADE}$ of infection and produce proinflammatory cytokines.

We tested the effect of polyphenols on both normal and enhanced infection because both sceneries may occur in dengue and involve induction of proinflammatory responses. Our results showed that in normal infection, DENV-2 induced more IL-6 (954 vs $89 \mathrm{pg} / \mathrm{mL}$ ), IFN- $\gamma$ (155 vs $106 \mathrm{pg} / \mathrm{mL}$ ) and IL-10 (165 vs $57 \mathrm{pg} / \mathrm{mL})$ than DENV-3; but they induced similar amounts of TNF- $\alpha$ (377 vs $365 \mathrm{pg} / \mathrm{ml}$ ).

U937-DC-SIGN cells infected with DENV-2 resembled M1 macrophages, because they produced high amounts of IL-6, high TNF- $\alpha$, low IL-10, low IFN- $\gamma$ and lack of IL-12. ${ }^{47}$ DENV-3 induced a quite similar profile of cytokines, but with lower IL-6 production.

In enhanced infection with 4G2 antibody, DENV-2 and DENV-3 induced high increase of TNF- $\alpha$ (1173 vs 789 pg/ $\mathrm{mL}$ ), lower secretion of IL-6 (103 vs $79 \mathrm{pg} / \mathrm{mL})$, and slight increase of IFN- $\gamma$ (192 vs 183 pg/mL) and IL-10 (107 vs 93 $\mathrm{pg} / \mathrm{mL}$ ). It is notable the amount of TNF- $\alpha$ produced in the infection enhanced by antibodies. This could be linked to cell signaling pathways activated either through the IgG Fc gamma receptor or through cell receptors recognized by DENV attachment proteins. Indeed, TNF- $\alpha$ and IL-6 synthesis is activated by the cross-linking between Fc gamma receptor and TLR. ${ }^{48}$ TNF- $\alpha$ is also induced through signaling by the C-type lectin CLEC5A ${ }^{40}$; meanwhile, secretion of IL-6 is mainly induced by recognition of viral RNA by cytoplasmic sensors that activate NF-кB signaling. ${ }^{49}$

The role of TNF- $\alpha$ in DENV pathogenesis is controversial. It is frequently found in the sera of dengue patients during the febrile phase of clinical disease. In addition, a protective role has been assigned to certain TNF- $\alpha$ gene allele polymorphisms. ${ }^{50}$ However, there are more evidence of its role in pathogenesis. Some studies showed that TNF$\alpha$ upregulates the phagocytosis of platelets and thus is involved in the origin of thrombocytopenia, an important clinical manifestation of dengue that includes increased destruction and reduced production of platelets. $^{51}$ CLEC5A has been also implicated in the induction of apoptosis and damage of endothelial cells in a murine model of DENV infection, in which the release of large amounts of TNF- $\alpha$, as well as IL-6 and MCP-1, conduced to several vascular leakage, organ damage, extensive hemorrhage and death of infected mice. ${ }^{40}$ A clinical trial showed the relevance of TNF- $\alpha$ measurement as part of the indicators of recovery in patients with severe dengue and thrombocytopenia; indeed, treatment with Propoelix $^{\mathrm{TM}}$ induced faster recovery in platelet counts and shorter length of hospitalization that were associated with lower levels of TNF- $\alpha$ in the treated group. ${ }^{52}$ Additional evidence of the role of TNF- $\alpha$, IL- 6 and other 
cytokines in dengue immunopathology comes from a study that prevent endothelial lesions in a murine model of dengue by direct blocking with antibodies against each cytokine. ${ }^{13}$ NS1 was recently identified as a pathogenic factor that is involved in vascular leakage and tissue damage by affecting the intercellular junctions of endothelial cells and inducing the release of enzymes that hydrolyze the extracellular matrix. ${ }^{53}$ It has been shown that NS1 induces the synthesis of proinflammatory cytokines. ${ }^{54}$ It is probable that the antiviral and immunomodulatory effects of quercetin and fisetin be mediated through interaction with NS1 as has been predicted by in silico studies. ${ }^{30}$ Further experimental studies are required to corroborate this hypothesis.

Previous studies showed that quercetin decreases DENV-2 replication in epithelial cell lines of nonhuman origin. ${ }^{25,26}$ Our results expand the knowledge of antiviral actions in cells that are the main targets of dengue infection. In addition, quercetin and fisetin showed inhibitory potential against two DENV serotypes and simultaneously modulate the production of TNF- $\alpha$ and IL-6. Other compounds tested such as curcumin modulate cytokine secretion but did not inhibit DENV replication in macrophages, although it showed previous antiviral activity in epithelial cells. ${ }^{55}$ This stands out the relevance of the cell model.

In addition to their antiviral activity, quercetin and fisetin showed regulatory effects on proinflammatory cytokines. Indeed, in macrophages infected with DENV-2, quercetin inhibited almost completely IL- 6 and TNF- $\alpha$ and slightly modifies the kinetics of IL-10 and IFN- $\gamma$ (Figure S1A-D). This is important because it reduces the deleterious effects of TNF- $\alpha$ and IL- 6 but did not modify the regulatory effect of IL-10 or the promotion of antiviral immune response induced by IFN- $\gamma$. Fisetin also inhibits IL- 6 and significantly down-regulates TNF- $\alpha$, IL-10 and IFN- $\gamma$ (Figure S1E-H). However, the effect of fisetin on TNF- $\alpha$ in DENV-3 occurred at early times after infection, but the cytokine recovers its levels after $48 \mathrm{hrs}$ of treatment (Figure S3F). It is probable that the remaining virus induced the reactivation of TNF- $\alpha$ secretion, but this is speculative. The compounds without significant antiviral activity such as apigenin, resveratrol and rutin did not modify TNF- $\alpha$ secretion at all; therefore, this corroborates that control of TNF- $\alpha$ could be used as an indicator of the response to antiviral treatment.

The production of proinflammatory cytokines is a matter of intense research because they play relevant roles in several human diseases. Proinflammatory cytokines such as TNF- $\alpha$ and IL-6 are secreted in response to TLR engagement and activation of mitogen-activated protein kinases (MAPK). It is known that MAPKs are required for efficient DENV replication and transcription of TNF- $\alpha$ gene. ${ }^{56,57}$ Quercetin reduces the activation of MAPK early after the treatment of tumor cells. ${ }^{58,59}$ The effect of quercetin is strong and prolonged in time; therefore, it avoids the autocrine action of TNF- $\alpha$ and inhibits further secretion of the cytokine. While quercetin is a strong inhibitor of MAPK, it has not been proven that fisetin is. Based on our results, we assume that fisetin has lower activity on MAPK or its effect on this pathway is short.

The regulatory role of quercetin depends on phosphatases such as MKP-1 that arrest the activation of MAPK signaling $^{60}$ and SHP-2 that stops phosphorylation in the Jak-STAT pathway, which is activated in response to IL-6 and TNF- $\alpha$. Quercetin also regulates the activity of the suppressors of cytokine signaling that control the time and intensity of cellular functions activated by cytokines. ${ }^{33} \mathrm{In}$ addition, the presence of other cytokines in the microenvironment of the infected cell plays important regulatory roles; indeed, IL-10 and TGF- $\beta$ down-regulate the synthesis of TNF- $\alpha$; meanwhile, IFN- $\gamma$ induces its synthesis. ${ }^{61,62}$ The later may be the reason why TNF- $\alpha$ recovers its levels in DENV-3-infected cells treated with fisetin because it coincides with higher IFN- $\gamma$ levels (Figure 6C).

It has been shown that flavonoids differ in their capacity to block the activity of several kinases including PI3K; the tyrosine SRC-family kinases Fyn, Lyn, Src and Syk; as well as PKC, ERK, JNK and PKA. Their direct action on kinases inhibits the activation of AP-1 and NF$\mathrm{kb}$ transcription factors and avoids the expression of COX2 which altogether arrests the proinflammatory signals and the synthesis of TNF- $\alpha .{ }^{59}$ While quercetin inhibits preferentially p38 and JNK, but not Src or ERK, ${ }^{58}$ fisetin has inhibitory actions on Src and Syk. Inactivation of Syk can be considered as a feedback signal that downregulates the synthesis of more TNF- $\alpha .{ }^{63}$

More studies are required to determine the precise antiviral mechanisms of quercetin and fisetin on dengue infection. Due to their relevance and diverse properties, the pharmacokinetics of flavonoids is under intense study to improve their bioavailability and effectiveness in the therapy against diverse human diseases. ${ }^{64,65}$

\section{Conclusion}

In search for specific therapy against DENV, quercetin and fisetin are potential candidates because they inhibit infection caused by two viral serotypes under different infection 
processes, in both cases down-regulating the secretion of TNF$\alpha$ associated with enhanced infection and severe dengue pathogenesis.

\section{Acknowledgments}

This work was supported by Mexican Institute of Social Security "IMSS" (grants FIS/IMSS/PROT/G17-2/1732 and CTFIS/10RD/12/2011) and by Secretary of Public Education - Redes temáticas (BUAP-CA-147). Carolina Jasso-Miranda had scholarships from National Council of Science and Technology CONACYT (No. 374373) and IMSS (98224279). Julio Reyes-Leyva has a research fellowship from Fundación IMSS A.C. None of these institutions participate, determine or interfere in any form with the design and development of the study, decision to publish or preparation of the manuscript.

\section{Disclosure}

The authors report no conflicts of interest in this work.

\section{References}

1. Bhatt S, Gething PW, Brady OJ, et al. The global distribution and burden of dengue. Nature. 2013;496(7446):504-507. doi:10.1038/ nature 12060

2. Gubler DJ. The economic burden of dengue. Am J Trop Med Hyg. 2012;86(5):743-744. doi:10.4269/ajtmh.2012.12-0157

3. Shepard DS, Undurraga EA, Halasa YA, Stanaway JD. The global economic burden of dengue: a systematic analysis. Lancet Infect Dis. 2016;16(8):935-941. doi:10.1016/S1473-3099(16)00146-8

4. Zubieta-Zavala A, Salinas-Escudero G, Ramírez-Chávez A, et al. Calculation of the average cost per case of dengue fever in Mexico using a micro-costing approach. PLoS Negl Trop Dis. 2016;10(8): e0004897. doi:10.1371/journal.pntd.0004897

5. World Health Organization. Dengue guidelines for diagnosis, treatment, prevention and control - New Edition; 2009. Available from: www.who.int/neglected_diseases/en. Accessed January 1, 2018.

6. Pan American Health Organization. Dengue Guidelines for Patient Care in the Region of the Americas. Washington, DC: Segunda; 2016. Available from: http://iris.paho.org/xmlui/bitstream/handle/123456789/ 31207/9789275118900-eng.pdf?sequence $=1$ \&isAllowed $=y$

7. Martina BEE, Koraka P, Osterhaus ADME. Dengue virus pathogenesis: an integrated view. Clin Microbiol Rev. 2009;22(4):564-581. doi:10.1128/CMR.00035-09

8. Green S, Rothman A. Immunopathological mechanisms in dengue and dengue hemorrhagic fever. Curr Opin Infect Dis. 2006;19 (5):429-436. doi:10.1097/01.qco.0000244047.31135.fa

9. Guzman MG, Alvarez M, Halstead SB. Secondary infection as a risk factor for dengue hemorrhagic fever/dengue shock syndrome: an historical perspective and role of antibody-dependent enhancement of infection. Arch Virol. 2013;158(7):1445-1459. doi:10.1007/ s00705-013-1645-3

10. Sun P, Bauza K, Pal S, et al. Infection and activation of human peripheral blood monocytes by dengue viruses through the mechanism of antibody-dependent enhancement. Virology. 2011;421 (2):245-252. doi:10.1016/j.virol.2011.08.026
11. Katzelnick LC, Gresh L, Halloran ME, et al. Antibody-dependent enhancement of severe dengue disease in humans. Science (80-). 2017;358(6365):929-932. doi:10.1126/science.aan6836

12. Kuczera D, Assolini JP, Tomiotto-Pellissier F, Pavanelli WR, Silveira GF. Highlights for dengue immunopathogenesis: antibody-dependent enhancement, cytokine storm, and beyond. J Interferon Cytokine Res. 2018;38(2):69-80. doi:10.1089/ jir.2017.0037

13. Puerta-Guardo H, Raya-Sandino A, González-Mariscal L, et al. The cytokine response of U937-derived macrophages infected through antibody-dependent enhancement of dengue virus disrupts cell apical-junction complexes and increases vascular permeability. J Virol. 2013;87(13):7486-7501. doi:10.1128/JVI.00085-13

14. Bozza FA, Cruz OG, Zagne SM, et al. Multiplex cytokine profile from dengue patients: MIP-1beta and IFN-gamma as predictive factors for severity. BMC Infect Dis. 2008;8(1):86. doi:10.1186/14712334-8-86

15. Butthep P, Chunhakan S, Yoksan S, Tangnararatchakit K, Chuansumrit A. Alteration of cytokines and chemokines during febrile episodes associated with endothelial cell damage and plasma leakage in dengue hemorrhagic fever. Pediatr Infect Dis J. 2012;31 (12):232-238. doi:10.1097/INF.0b013e31826fd456

16. Green S, Vaughn DW, Kalayanarooj S, et al. Elevated plasma interleukin-10 levels in acute dengue correlate with disease severity. J Med Virol. 1999;59(3):329-334. Available from: http://www.ncbi. nlm.nih.gov/pubmed/10502265. Accessed, 2017.

17. Flores-Mendoza LK, Estrada-Jiménez T, Sedeño-Monge V, et al. IL10 and socs 3 are predictive biomarkers of dengue hemorrhagic fever. Mediators Inflamm. 2017;2017:1-10. doi:10.1155/2017/5197592

18. Chen R-F, Yang KD, Lee I-K, et al. Augmented miR-150 expression associated with depressed SOCS1 expression involved in dengue haemorrhagic fever. $J$ Infect. 2014;69(4):366-374. doi:10.1016/j. jinf.2014.05.013

19. Rajapakse S, Rodrigo C, Rajapakse A. Treatment of dengue fever. Infect Drug Resist. 2012;5:103. doi:10.2147/IDR.S22613

20. Whitehorn J, Yacoub S, Anders KL, et al. Dengue therapeutics, chemoprophylaxis, and allied tools: state of the art and future directions. Rothman AL, ed. PLoS Negl Trop Dis. 2014;8(8):e3025. doi:10.1371/journal.pntd.0003025

21. Low JGH, Ooi EE, Vasudevan SG. Current status of dengue therapeutics research and development. J Infect Dis. 2017;215(suppl_2): S96-S102. doi:10.1093/infdis/jiw423

22. Petrovska BB. Historical review of medicinal plants' usage Pharmacogn Rev. 2012;6(11):1-5. doi:10.4103/0973-7847.95849

23. Sanchez I, Gomez-Garibay F, Taboada J, Ruiz BH. Antiviral effect of flavonoids on the dengue virus. Phyther Res. 2000;14(2):89-92. doi:10.1002/(SICI)1099-1573(200003)14:2<89::AID-PTR569>3.0. $\mathrm{CO} ; 2-\mathrm{C}$

24. Whitby K, Pierson TC, Geiss B, et al. Castanospermine, a potent inhibitor of dengue virus infection in vitro and in vivo. $J$ Virol. 2005;79(14):8698-8706. doi:10.1128/JVI.79.14.8698-8706.2005

25. Zandi K, Teoh B-T, Sam -S-S, Wong P-F, Mustafa M, AbuBakar S. Antiviral activity of four types of bioflavonoid against dengue virus type-2. Virol J. 2011;8(1):560. doi:10.1186/1743-422X-8-560

26. Zandi K, Lim T-H, Rahim N-A, et al. Extract of scutellaria baicalensis inhibits dengue virus replication. BMC Complement Altern Med. 2013;13:91. doi:10.1186/1472-6882-13-91

27. Lanciotti RS, Calisher CH, Gubler DJ, Chang GJ, Vorndam AV. Rapid detection and typing of dengue viruses from clinical samples by using reverse transcriptase-polymerase chain reaction. $J$ Clin Microbiol. 1992;30(3):545-551. Available from: http://www.ncbi. nlm.nih.gov/pubmed/1372617. Accessed, 2018.

28. Halstead SB. Dengue antibody-dependent enhancement: knowns and unknowns. In: Antibodies for Infectious Diseases. Vol. 2. American Society of Microbiology;2014:249-271. doi:10.1128/microbiolspec. AID-0022-2014 
29. Ismail NA, Jusoh SA. Molecular docking and molecular dynamics simulation studies to predict flavonoid binding on the surface of DENV2 E protein. Interdiscip Sci Comput Life Sci. 2017;9 (4):499-511. doi:10.1007/s12539-016-0157-8

30. Qamar MTU, Mumtaz A, Naseem R, et al. Molecular docking based screening of plant flavonoids as dengue NS1 inhibitors. Bioinformation. 2014;10(7):460-465. doi:10.6026/97320630010460

31. de Sousa LRF, Wu H, Nebo L, et al. Flavonoids as noncompetitive inhibitors of dengue virus NS2B-NS3 protease: inhibition kinetics and docking studies. Bioorg Med Chem. 2015;23(3):466-470. doi:10.1016/j.bmc.2014.12.015

32. Senthilvel P, Lavanya P, Kumar KM, et al. Flavonoid from Carica papaya inhibits NS2B-NS3 protease and prevents dengue 2 viral assembly. Bioinformation. 2013;9(18):889-895. doi:10.6026/97320630009889

33. Igbe I, Shen X-F, Jiao W, et al. Dietary quercetin potentiates the antiproliferative effect of interferon- $\alpha$ in hepatocellular carcinoma cells through activation of JAK/STAT pathway signaling by inhibition of SHP2 phosphatase. Oncotarget. 2017;8(69):113734-113748. doi:10.18632/oncotarget.22556

34. Ashour J, Laurent-Rolle M, Shi P-Y, Garcia-Sastre A. NS5 of dengue virus mediates STAT2 binding and degradation. $J$ Virol. 2009;83 (11):5408-5418. doi:10.1128/JVI.02188-08

35. Estrada-Jiménez T, Millán-Pérez Peña L, Flores-Mendoza L, et al. Upregulation of the suppressors of cytokine signaling 1 and 3 is associated with arrest of phosphorylated-STAT1 nuclear importation and reduced innate response in denguevirus-infected macrophages. Viral Immunol. 2016;29(2):95-104. doi:10.1089/vim.2014.0136

36. Ubol S, Phuklia W, Kalayanarooj S, Modhiran N. Mechanisms of immune evasion induced by a complex of dengue virus and preexisting enhancing antibodies. $J$ Infect Dis. 2010;201(6):923-935. doi:10.1086/651018

37. Palma-Ocampo HK, Flores-Alonso JC, Vallejo-Ruiz V, et al. Interferon lambda inhibits dengue virus replication in epithelial cells. Virol J. 2015;12:1. doi:10.1186/s12985-015-0383-4

38. Wiejak J, Dunlop J, Mackay SP, Yarwood SJ. Flavanoids induce expression of the suppressor of cytokine signalling 3 (SOCS3) gene and suppress IL-6-activated signal transducer and activator of transcription 3 (STAT3) activation in vascular endothelial cells. Biochem J. 2013;454(2):283-293. doi:10.1042/BJ20130481

39. Kou Z, Quinn M, Chen H, et al. Monocytes, but not T or B cells, are the principal target cells for dengue virus (DV) infection among human peripheral blood mononuclear cells. J Med Virol. 2008;80 (1):134-146. doi:10.1002/jmv.21051

40. Chen S-T, Lin Y-L, Huang M-T, et al. CLEC5A is critical for dengue-virus-induced lethal disease. Nature. 2008;453 (7195):672-676. doi:10.1038/nature07013

41. Lo Y-L, Liou -G-G, Lyu J-H, Hsiao M, Hsu T-L, Wong C-H. Dengue virus infection is through a cooperative interaction between a mannose receptor and CLEC5A on macrophage as a multivalent hetero-complex. Pöhlmann S, ed. PLoS One. 2016;11(11):e0166474. doi:10.1371/journal.pone. 0166474

42. Miller JL, de Wet BJM, de Wet BJM, et al. The mannose receptor mediates dengue virus infection of macrophages. PLoS Pathog. 2008;4(2):e17. doi:10.1371/journal.ppat.0040017

43. Tassaneetrithep B, Burgess TH, Granelli-Piperno A, et al. DC-SIGN (CD209) mediates dengue virus infection of human dendritic cells. J Exp Med. 2003;197(7):823-829. doi:10.1084/jem.20021840

44. Lozach P-Y, Burleigh L, Staropoli I, et al. Dendritic cell-specific intercellular adhesion molecule 3-grabbing non-integrin (DC-SIGN)mediated enhancement of dengue virus infection is independent of DC-SIGN internalization signals. $J$ Biol Chem. 2005;280 (25):23698-23708. doi:10.1074/jbc.M504337200

45. Chan KR, Zhang SL-X, Tan HC, et al. Ligation of Fc gamma receptor IIB inhibits antibody-dependent enhancement of dengue virus infection. Proc Natl Acad Sci $U$ S A. 2011;108 (30):12479-12484. doi:10.1073/pnas.1106568108
46. Bournazos S, Wang TT, Dahan R, Maamary J, Ravetch JV. Signaling by antibodies: recent progress. Annu Rev Immunol. 2017;35 (1):285-311. doi:10.1146/annurev-immunol-051116-052433

47. Palma A, Jarrah AS, Tieri P, Cesareni G, Castiglione F. Gene regulatory network modeling of macrophage differentiation corroborates the continuum hypothesis of polarization states. Front Physiol. 2018;9:1659. doi:10.3389/fphys.2018.01659

48. Vogelpoel LTC, Hansen IS, Rispens T, et al. Fc gamma receptor-TLR cross-talk elicits pro-inflammatory cytokine production by human M2 macrophages. Nat Commun. 2014;5(1):5444. doi:10.1038/ ncomms 6444

49. Hoesel B, Schmid JA. The complexity of NF-kB signaling in inflammation and cancer. Mol Cancer. 2013;12(1):86. doi:10.1186/14764598-12-86

50. Sam -S-S, Teoh B-T, Chinna K, AbuBakar S. High producing tumor necrosis factor alpha gene alleles in protection against severe manifestations of dengue. Int $J$ Med Sci. 2015;12(2):177-186. doi:10.7150/ijms. 8988

51. Wan S-W, Yang Y-W, Chu Y-T, et al. Anti-dengue virus nonstructural protein 1 antibodies contribute to platelet phagocytosis by macrophages. Thromb Haemost. 2016;115(03):646-656. doi:10.1160/th15-06-0498

52. Lardo S, Wibisono D, Sulistyo B, Purnama Y. The effect of a unique propolis compound (PropoelixTM) on clinical outcomes in patients with dengue hemorrhagic fever. Infect Drug Resist. 2014;323. doi:10.2147/IDR.S71505

53. Puerta-Guardo H, Glasner DR, Harris E. Dengue virus NS1 disrupts the endothelial glycocalyx, leading to hyperpermeability. Kuhn RJ, ed. PLoS Pathog. 2016;12(7):e1005738. doi:10.1371/journal. ppat. 1005738

54. Alayli F, Scholle F. Dengue virus NS1 enhances viral replication and pro-inflammatory cytokine production in human dendritic cells. Virology. 2016;496:227-236. doi:10.1016/j.virol.2016.06.008

55. Padilla-S L, Rodríguez A, Gonzales MM, Gallego-G JC, Castaño-O JC. Inhibitory effects of curcumin on dengue virus type 2-infected cells in vitro. Arch Virol. 2014;159(3):573-579. doi:10.1007/s00705-013-1849-6

56. Nagila A, Netsawang J, Suttitheptumrong A, et al. Inhibition of p38MAPK and CD137 signaling reduce dengue virus-induced TNF$\alpha$ secretion and apoptosis. Virol J. 2013;10(1):105. doi:10.1186/1743422X-10-105

57. Sreekanth GP, Yenchitsomanus P, Limjindaporn T. Role of mitogen-activated protein kinase signaling in the pathogenesis of dengue virus infection. Cell Signal. 2018;48:64-68. doi:10.1016/j. cellsig.2018.05.002

58. Endale M, Park S-C, Kim S, et al. Quercetin disrupts tyrosinephosphorylated phosphatidylinositol 3-kinase and myeloid differentiation factor-88 association, and inhibits MAPK/AP-1 and IKK/NF- $\mathrm{kB}$-induced inflammatory mediators production in RAW 264.7 cells. Immunobiology. 2013;218(12):1452-1467. doi:10.1016/j.imbio.2013.04.019

59. Wright B, Watson KA, McGuffin LJ, Lovegrove JA, Gibbins JM. GRID and docking analyses reveal a molecular basis for flavonoid inhibition of Src family kinase activity. J Nutr Biochem. 2015;26 (11):1156-1165. doi:10.1016/j.jnutbio.2015.05.004

60. Chi H, Barry SP, Roth RJ, et al. Dynamic regulation of pro- and anti-inflammatory cytokines by MAPK phosphatase 1 (MKP-1) in innate immune responses. Proc Natl Acad Sci. 2006;103 (7):2274-2279. doi:10.1073/pnas.0510965103

61. Donnelly RP, Freeman SL, Hayes MP. Inhibition of IL-10 expression by IFN-gamma up-regulates transcription of TNF-alpha in human monocytes. J Immunol. 1995;155(3):1420-1427. Available from: http://www.ncbi.nlm.nih.gov/pubmed/7636207. Accessed, 2019.

62. Bogdan C, Paik J, Vodovotz Y, Nathan C. Contrasting mechanisms for suppression of macrophage cytokine release by transforming growth factor-beta and interleukin-10. J Biol Chem. 1992;267 (32):23301-23308. Available from: http://www.ncbi.nlm.nih.gov/ pubmed/1429677. Accessed, 2019. 
63. Kim JH, Kim MY, Kim JH, Cho JY. Fisetin suppresses macrophage-mediated inflammatory responses by blockade of Src and Syk. Biomol Ther. 2015;23(5):414-420. doi:10.4062/ biomolther.2015.036

64. Terao J. Factors modulating bioavailability of quercetin-related flavonoids and the consequences of their vascular function. Biochem Pharmacol. 2017;139:15-23. doi:10.1016/j.bcp.2017.03.021
65. Manach C, Donovan JL. Pharmacokinetics and metabolism of dietary flavonoids in humans. Free Radic Res. 2004;38(8):771-785. http:// www.ncbi.nlm.nih.gov/pubmed/15493450. Accessed, 2019. 


\section{Supplementary materials}

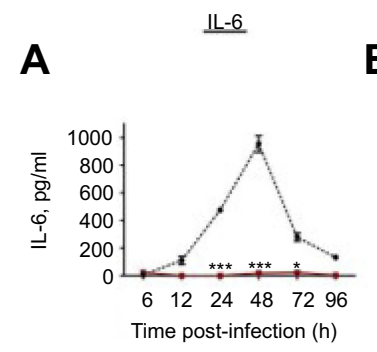

E

$\underline{\text { Fisetin }}$

Apigenin

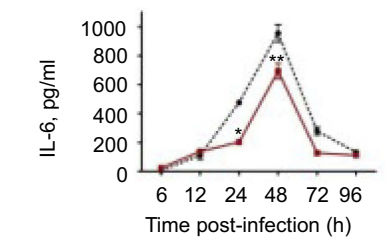

\section{Q}

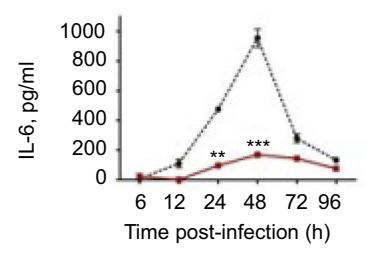

$\mathbf{U}$

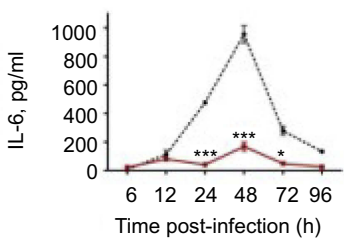

I

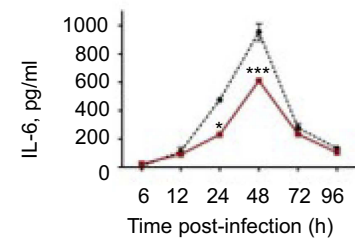

M

Curcumin

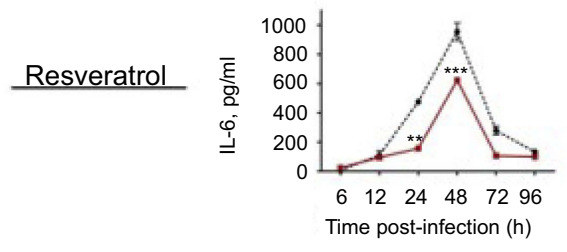

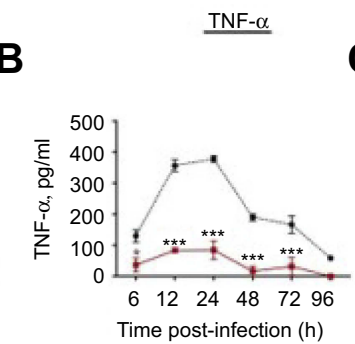

$\mathbf{F}$

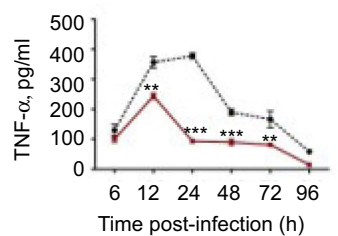

J

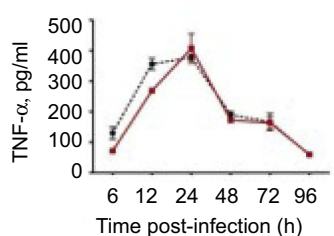

$\mathbf{N}$

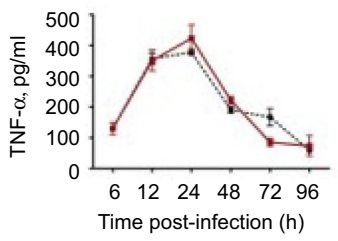

$\mathbf{R}$

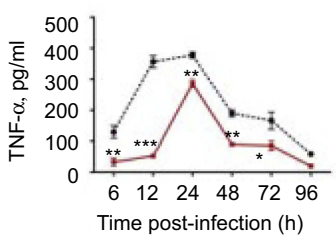

V

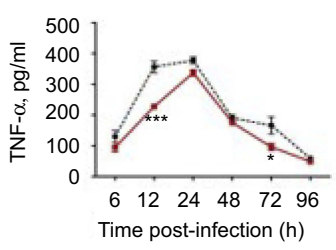

C

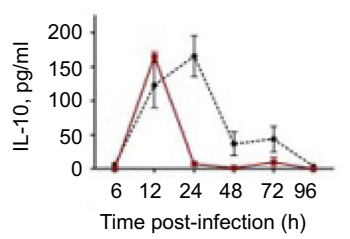

G

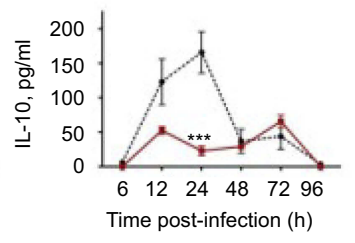

K

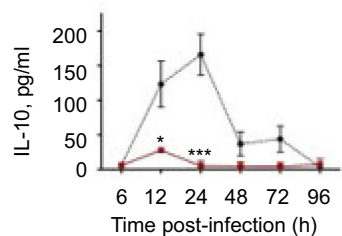

O

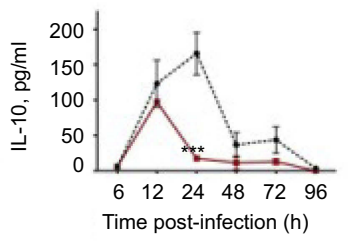

S

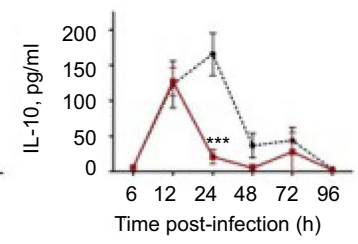

W

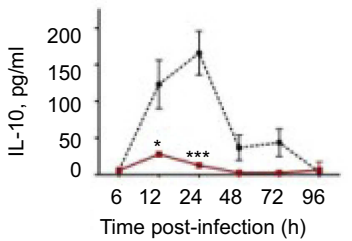

D

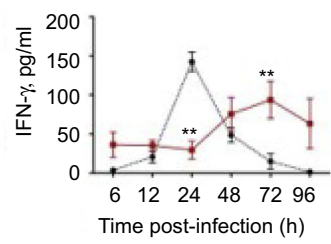

H

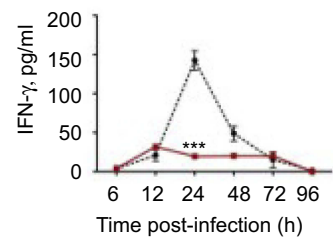

$\mathbf{L}$

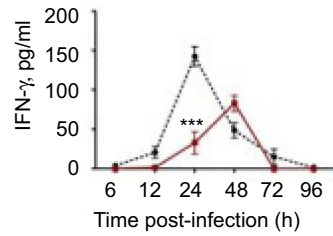

$\mathbf{P}$

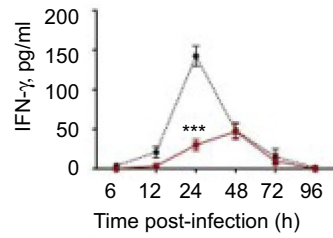

T

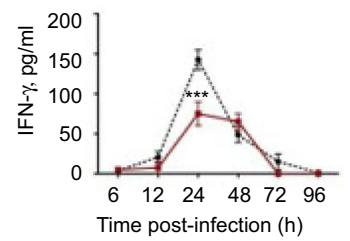

$\mathbf{X}$

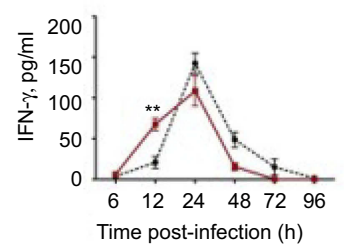

- - DENV-2 (Untreated control)

DENV-2 + Treatment

Figure SI Cytokine secretion in DENV-2 infected macrophages treated with polyphenols. Kinetics of cytokine production was determined in U937-DC-SIGN macrophages infected with DENV-2 at a MOI=I. Cells were untreated or treated at I hr after infection with $100 \mu \mathrm{M}$ quercetin (A-D), $40 \mu \mathrm{M}$ fisetin $(\mathbf{E}-\mathbf{H}), 40 \mu \mathrm{M}$ apigenin $(\mathbf{I}-\mathbf{L}), \mathrm{I} 00 \mu \mathrm{M}$ rutin $(\mathbf{M}-\mathbf{P}), 20 \mu \mathrm{M}$ curcumin $(\mathbf{Q}-\mathbf{T})$ or $100 \mu \mathrm{M}$ resveratrol $(\mathbf{U}-\mathbf{X})$. Cell supernatants were collected at different times after infection $(6,12,24,48,72$ and $96 \mathrm{hrs})$ and the concentrations of IL-6, TNF- $\boldsymbol{\alpha}$, IL- 10 and IFN- $\gamma$ were determined by ELISA. Data represent average \pm SD of two independent and duplicated experiments; data were analyzed by two-way Anova with subsequent Bonferroni's test using GraphPad Prism 5.0. Asterisks represent statistical significance $\left({ }^{*} p<0.05 ; * * p<0.01\right.$; $\left.* * * p<0.00 \mathrm{I}\right)$ between untreated and treated macrophages. Abbreviations: DENV, dengue virus; $\mathrm{MOI}$, multiplicity of infection. 


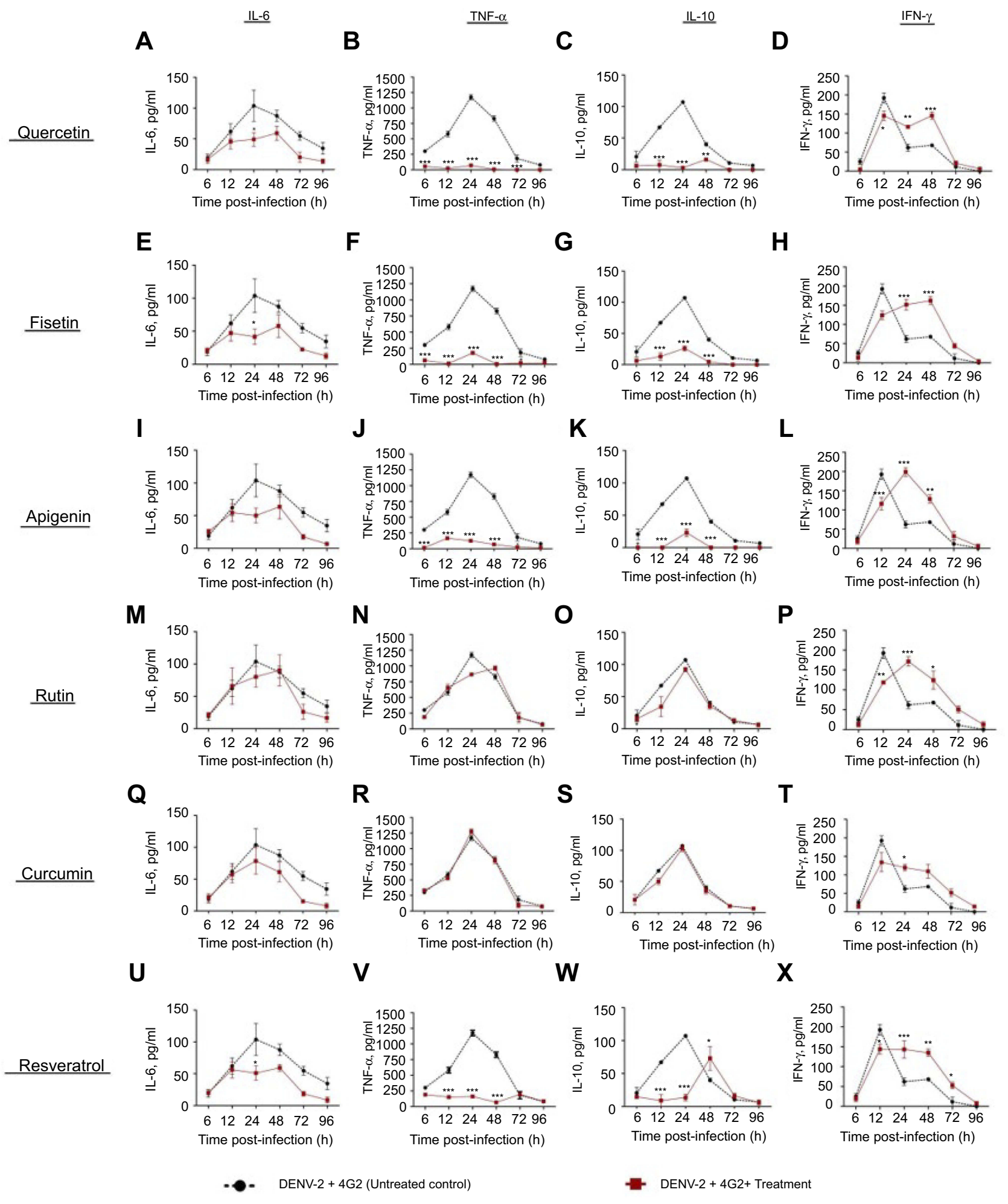

Figure S2 Effect of polyphenols on cytokine secretion in macrophages infected with DENV-2-4G2 antibody complexes. Macrophages were infected with mixtures of DENV2 at a MOI of I and 4G2 antibody at I:I024 dilution. Cells were untreated or treated at I hr after infection with $100 \mu M$ quercetin $(\mathbf{A}-\mathbf{D}), 40 \mu \mathrm{M}$ fisetin (E-H), $40 \mu \mathrm{M}$ apigenin (I-L), $100 \mu \mathrm{M}$ rutin (M-P), $20 \mu \mathrm{M}$ curcumin $(\mathbf{Q}-\mathbf{T})$ or $100 \mu \mathrm{M}$ resveratrol $(\mathbf{U}-\mathbf{X})$. Cell supernatants were collected at different times after infection $(6,12,24,48$, 72 and $96 \mathrm{hrs}$ ) and the concentrations of IL-6, TNF- $\alpha$, IL-I0 and IFN- $\gamma$ were determined by ELISA. Data represent average \pm SD of two independent and duplicated experiments; data were analyzed by two-way Anova with subsequent Bonferroni's test using GraphPad Prism 5.0. Asterisks represent statistical significance $(* p<0.05$; $* * p<0.0$ I; **** $p<0.00$ I) between untreated and treated macrophages.

Abbreviations: DENV, dengue virus; MOI, multiplicity of infection. 


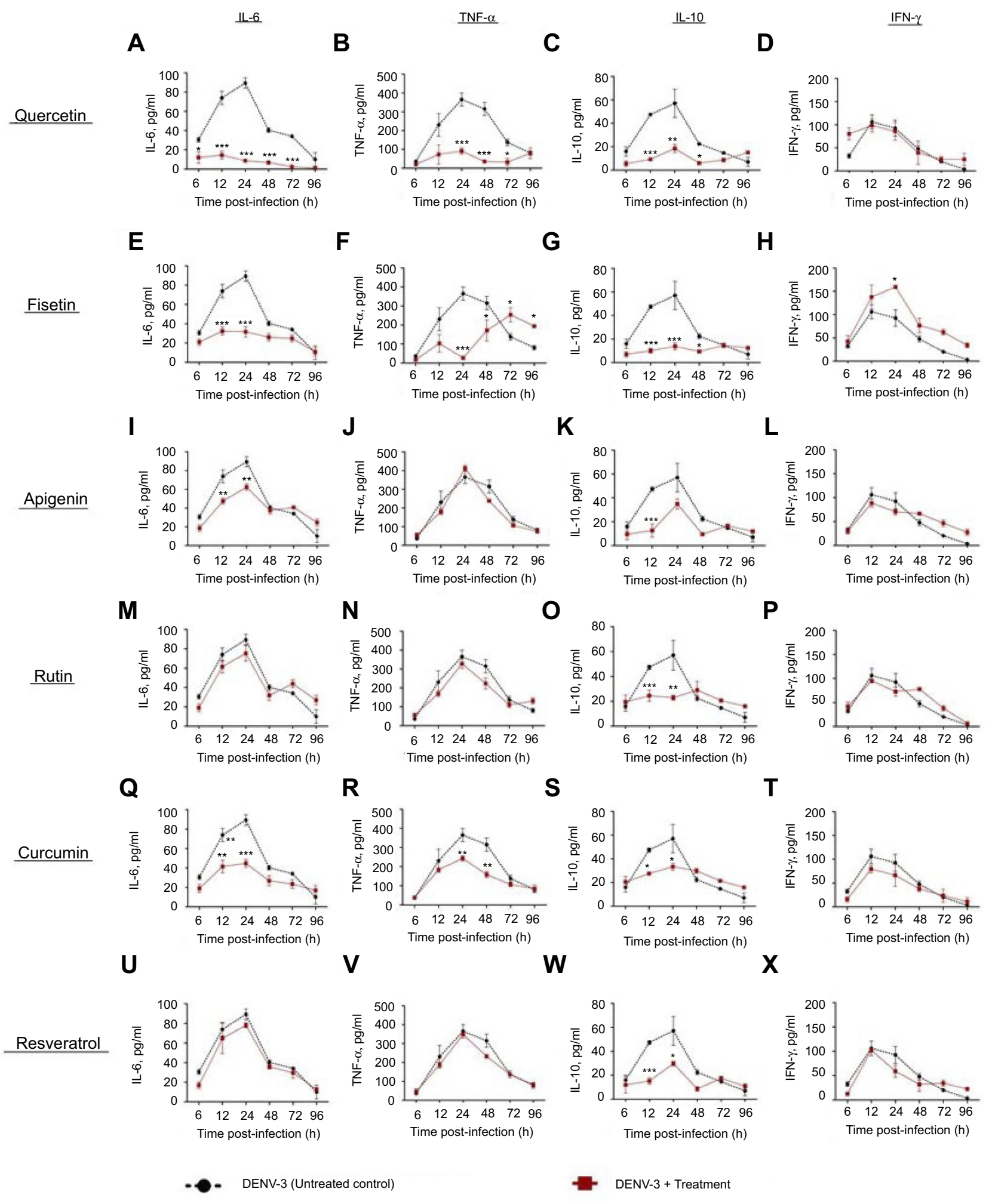

Figure S3 Cytokine secretion in DENV-3 infected macrophages treated with polyphenols. Kinetics of cytokine production was determined in U937-DC-SIGN macrophages infected with DENV-3 at a MOI=I. Cells were untreated or treated at I hr after infection with $100 \mu$ quercetin (A-D), $40 \mu M$ fisetin $(\mathbf{E}-\mathbf{H}), 40 \mu \mathrm{M}$ apigenin $(\mathbf{I}-\mathbf{L}), 100 \mu \mathrm{M}$ rutin (M-P), $20 \mu \mathrm{M}$ curcumin $(\mathbf{Q}-\mathbf{T})$ or $100 \mu \mathrm{M}$ resveratrol $(\mathbf{U}-\mathbf{X})$. Cell supernatants were collected at different times after infection $(6,12,24,48,72$ and $96 \mathrm{hrs})$ and the concentrations of IL-6, TNF- $\boldsymbol{\alpha}$, IL-10 and IFN- $\gamma$ were determined by ELISA. Data represent average \pm SD of two independent and duplicated experiments; data were analyzed by two-way Anova with subsequent Bonferroni's test using GraphPad Prism 5.0. Asterisks represent statistical significance $\left({ }^{*} p<0.05 ; * * p<0.01 ; * * * p<0.001\right)$ between untreated and treated macrophages.

Abbreviations: DENV, dengue virus; MOI, multiplicity of infection. 


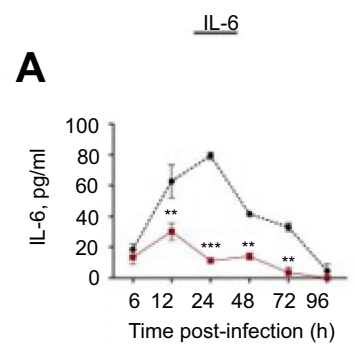

\section{E}

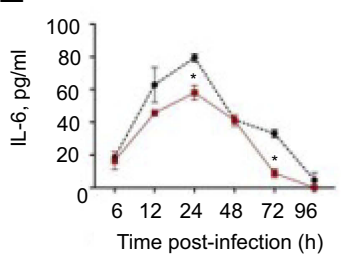

I

Apigenin

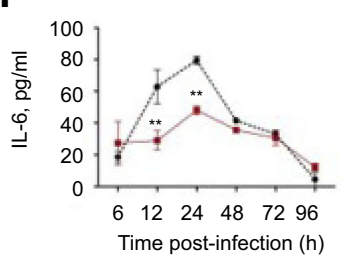

M

$\underline{\text { Rutin }}$

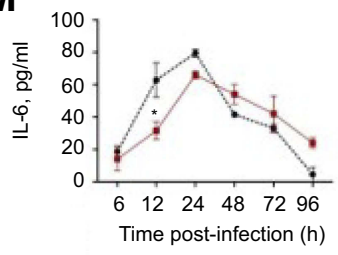

Q

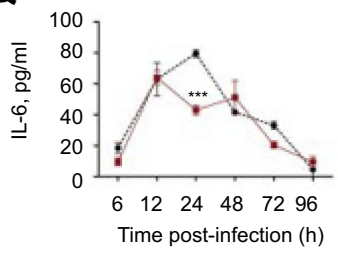

U

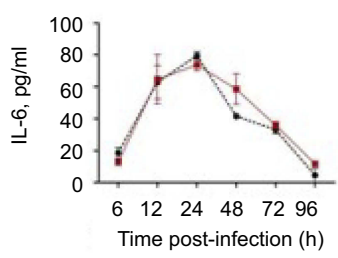

B

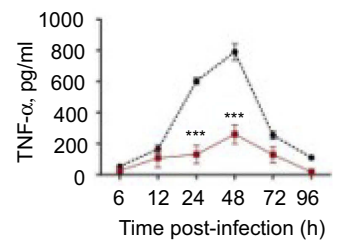

F

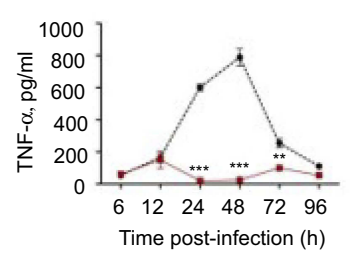

J

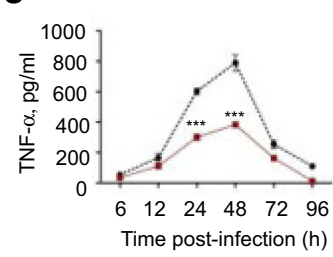

N

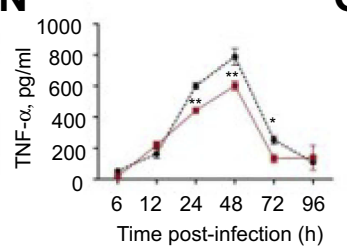

$\mathbf{R}$

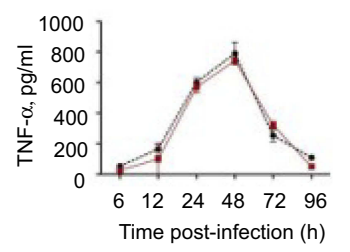

V

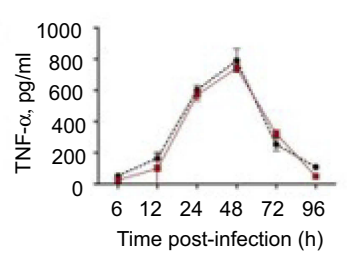

C

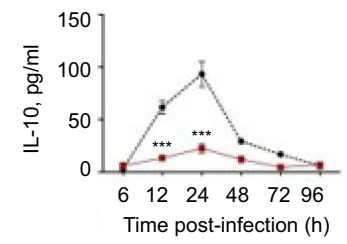

G

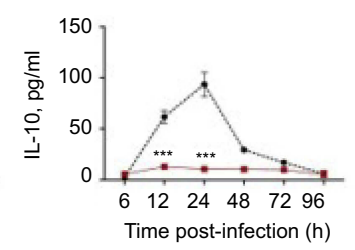

K

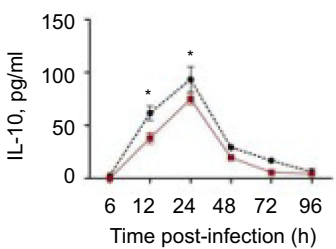

0

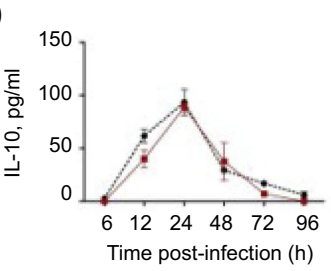

S

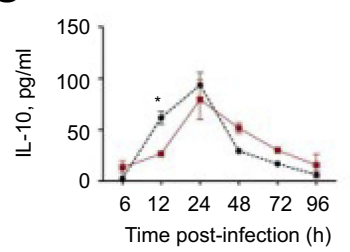

W

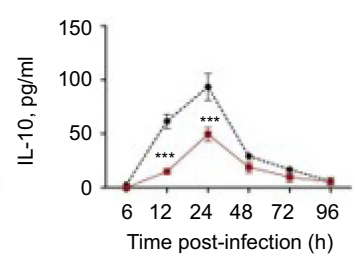

$\underline{\text { IFN- } \gamma}$

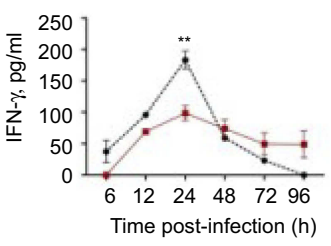

H

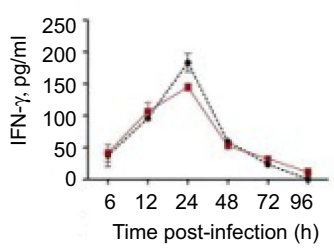

L

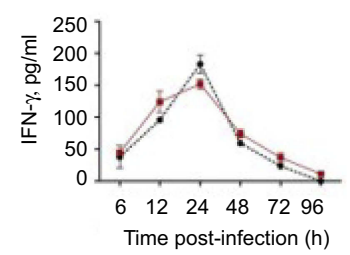

P

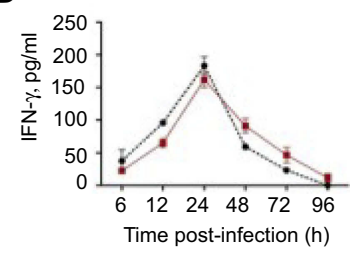

T

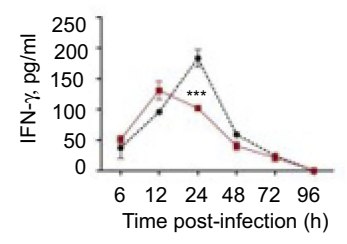

$\mathbf{X}$

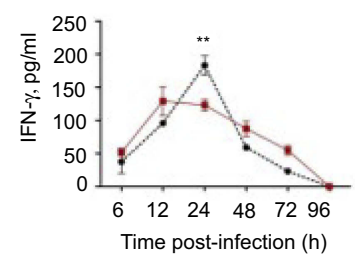

- - DENV-3 + 4G2 (Untreated control)

DENV-3 + 4G2 + Treatment

Figure S4 Effect of polyphenols on cytokine secretion in macrophages infected with DENV-2-4G2 antibody complexes. Macrophages were infected with mixtures of DENV3 at a $\mathrm{MOI}$ of I and 4G2 antibody at I:256 dilution. Cells were untreated or treated at I hr after infection with $100 \mu M$ quercetin $(\mathbf{A}-\mathbf{D})$, $40 \mu \mathrm{M}$ fisetin (E-H), $40 \mu \mathrm{M}$ apigenin (I-L), $100 \mu \mathrm{M}$ rutin (M-P), $20 \mu \mathrm{M}$ curcumin (Q-T) or $100 \mu \mathrm{M}$ resveratrol (U-X). Cell supernatants were collected at different times after infection (6, I2, 24, 48, 72 and 96 hrs) and the concentrations of IL-6, TNF- $\alpha$, IL-I0 and IFN- $\gamma$ were determined by ELISA. Data represent average \pm SD of two independent and duplicated experiments; data were analyzed by two-way Anova with subsequent Bonferroni's test using GraphPad Prism 5.0. Asterisks represent statistical significance $(* p<0.05$; $* * p<0.01 ; * * * p<0.00 I$ ) between untreated and treated macrophages.

Abbreviations: DENV, dengue virus; MOI, multiplicity of infection. 


\section{Publish your work in this journal}

Infection and Drug Resistance is an international, peer-reviewed openaccess journal that focuses on the optimal treatment of infection (bacterial, fungal and viral) and the development and institution of preventive strategies to minimize the development and spread of resistance. The journal is specifically concerned with the epidemiology of

antibiotic resistance and the mechanisms of resistance development and diffusion in both hospitals and the community. The manuscript management system is completely online and includes a very quick and fair peerreview system, which is all easy to use. Visit http://www.dovepress.com/ testimonials.php to read real quotes from published authors. 